OP

Aa

y

Bal

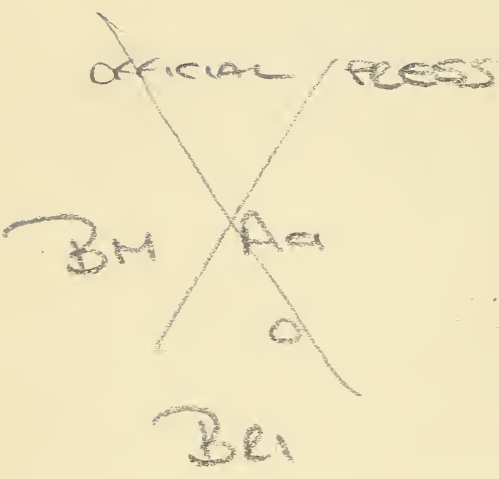

Natural History Museum Library<smiles>C#C[AsH3]</smiles> 




\section{thef SYNOPSIS}

of

$\mathbb{T H} \mathbb{E} \subset \mathbb{C} O \mathbb{T} \mathbb{N} \mathbb{T S}$

OF THR

\section{BRITISH MUSEUM.}

\section{LONDON :}

PRINTED BY COX AND BAYLIS,

No. 75, Great Queen Street, Lincoln's-Inn-Fizlds,

1813. 
MVSEVM BRTTAN NICVM

it 202 


\section{INTRODUCTION。}

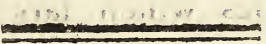

Persons who are desirous to obtain a general idea of the contents of this extensive Repository, will probably be gratified by having a brief statement previously laid before them;-I. Of the Circumstances which gave rise to the Institution;-II. Of its Gradual Increase;-III. Of its Constitution, and the Regulations now in force for its preservation and useful application;-and IV. Of the present distribution of its numerous contents, in the several Departments into which it is divided.

I.

FOUNDATION BY PARLIAMENT.

The project of a public establishment of this The Slcanear aature was first suggested by the will of Sir 
Hans Sloane, late of Chelsea, in the County of Middlesex, Bart.; who, during a long period of eminent practice in physic, had accumulated a very large collection of natural and artificial curiosities, together with a numerous library of printed books as well as manuscripts; and who, being well aware how much science is benefited by the opportunities which large aggregates of objects afford for comparing them together, and marking their less obvious differences, was very solicitous that his sumptuous Museum, which he declared in his last will had cost hirn upwards of $£ 50,000$, should, if possible, be preserved intire, and permanently dedicated to public utility.

With this riew he directed that the whole of his Museum should be offered to the British Parliament for the moderate sum of $£ 20,000$; that, should this tender not be accepted, the offer should be then made to certain foreign Academies named in the will; and that, should these also decline the offer, his Executors should be at liberty to dispose of it in the manner that should appear to them most eligible.

Sir Hans Sloane having died in the beginning of the year 1753, the offer directed in his will was immediately made to Parliament, and was accepted 
accepted without hesitation. Before the expiration of that year an Act was passed, which ordered the payment of the stipulated sum to his Executors and vested the property of the Museum in Trustees for the use of the Public.*

* Fror a schedule which was hander about at the time of the purchase, we collect the following totais of the contents of this Museum; but as this document is by no means authentic, we must request our reajers to consider these numbers rather as approximatious than as accurate enumerations.

Library of printed books and manuscripts, including bocks of prints and drawings............................ Vols. 50,000 Coins and medals........................................... 23,000

Antique idols, utensils, \&c............................ 1,125

Cameos, intaglios, seals, \&c............................. 1,500

Vessels and uterisils of agate, jasper, \&c.................... $\quad 542$

Anatomical preparations of human bodies, parts of mummies, calculi, \&.c........................................ 756

Quadrupeds and their parts................................. 8, 186

Birds and their parts, eggs and nests...................... 1,172

Fishes and their parts................................... 1,555

Amphibia ................................................. 521

Crustacea ....................................................... 1,436

Shells, echini, entrochi................................. 5,845

Insects ................................................ $5,3 \mathrm{~g} 4$

Corals, spunges, zoophytes................................ 1,421

Stones, ores, bitumens, salts, \&c........................ 9,942

Volumes of dried plants.,................................. 334

Mathematical Insiruments .............................. $\$ 5$

Miscellaneous artificial curiosities........................... 2, 0,8

M S. catalogues of the whole Museum, 38 vols. fol. and 8 gुuarto. 
The Cottonian Library.

A beginning having thus been made of a public scientific Repository, it was deemed expedient to enlarge its extent, and increase its importance, by adding to it whatever happened to be at that time within the reach of the Legislature. Accordingly Parliament having; by various successive acts and resolutions, obtained the full possession of the library of manuscripts collected by Sir Robert Cotton, in the times of Queen Elizabeth and James I., and increased by his son, Sir Thomas Cotton, in the subsequent reign, provided in the above-mentioned Act that this collection should be made a part of the intended National Mu. seum.*

Concerning this Library, which has ever been deemed an inestimable treasure, chiefly abounding in authentic documents relating to the history, the antiquities, the laws, and constitution of these Realms, and also in many ancient and splendid biblical and liturgick volumes, chronicles, and a variety of political tracts, we shall only remark at present that it now consists of 861 volumes;

* From the preamble to the act of Parliament, 12 and 13 of William III. cap. 7 , it may be gathered, that the public is chiefly indebted for this Library to the liberality of Sir John Cotton, Bart. grandson to the furst collecior. 
of which 54 are so much damaged by a fire, which happened in the year 1731, as to be almost useless. We are thus brief in our account of this important library, as more ample infurmation may easily be gathered from the prefaces to the catalogue compiled by Dr. Smyth and published in the year 1696; and the more enlarged one printed in 1802 , by order of His Majesty.

Besides these manuscripts, the collection contained also a considerable number of coins, chiefly Saxon and old English, and several Roman and British antiquities, which are now incurporated in their proper classes at the Museum.

As an appendage to the Cottonian Library, Majnr Edwards" there was likewise at the disposal of Parliament Library. a collection of about 2,000 volumes of English, French, and Italian books, formed by Major Arthur Edwards, late of St. George, Hanover Square, and by his will, made in the year 1738, bequeathed to the Trustees of the Cottonian Library, together with the reversion of the sum of $£ 7,000$, for the purpose of erecting a building or repository, properly adapted for the effective prese rvation 
preservation of the two joint libraries. This addition, of course, became likewise a part of the new foundation; and, the necessity of erecting a building being thus superseded by the transter of the libraries to the Museum, the above legacy of $£ 7,000$, when it devolved in the year 1769 , was placed in the public funds: and the interest accruing from it was, conformably to the intention of the testator, and the provisions of the Act of Parliament, ordered to be expended in the purchase of books, manuscripts, coins, and other curiosities; by which means considerable additions have from time to time been made, and continue to be made to the general Repository.

The Harleian Collection of Manuscripts.
'Parliament also, with the same liberal spirit of promoting the purposes of literature, caused an offer to be made to the Countess of Oxford, relict of Edward Earl of Oxford, and the Duchess of Portiand, their only daughter, for the purchase of the numerous and valuable Library of manuscripts collected by the said Earl, and by Robert Earl of Oxford, his father. The sum offered was $\mathcal{E} 10,000$; and the condition was annexed, that the Library, under the name of the Harleian Collection of Manuscripts, should be kept together, 
ther, as an addition to the Cottonian Library. This offer was willingly accepted; and a clause was inserted in the Act, ordering the payment of the above mentioned sum to the parties above named, and that the collection be disposed of according to the conditions of the purchase.

This Library, consisting of upwards of 7,600 volumes, many of them, as is usual in all MS. collections, containing a great number of separate articles, and upwards of 40,000 original rolls, charters, and other instruments, among which there are many of great antiquity, the whole, chiefly relating to the political, parliamentary, and ecclesiastical, history of Great Britain, and Ireland, is now placed according to its destina. tion. A general view of its contents is given in the preface of the catalogue of the Library printed in the year 1759, in two volumes folio.

In order to defray the expences necessarily implied by these purchases, and to provide a proper Repository for the preservation of them, as well as a fund for the permanent support of the establishment, Parliament resolved to raise the sum of $£ 100,000$ by way of Iottery; which having been drawn according to the 
provisions laid down in the Act, netted the sum of $£ 95,194.8 s .2 d$. This sum, together with the several collections, purchased and granted as above stated, Parliament vested in an incorporate body of Trustees, consisting of the first characters in the kingdom for rank, station, and literary fame; at the same time conferring on them ample powers to take such measures as they shall deem expedient for the disposal, preservation, and management of the Institution, which it was now determined should bear the name of the British Museum.

Montague House.

The first act of these Trustees was to provide a proper building for the reception of the ample collections confided to their care; and after various proposals, they at length fixed upon the noble mansion, built about the year 1680, by Ralph first Duke of Montague, who being at that time Ambassadour at Paris, sent over French artists for erecting and adorning the edifice he had in contemplation. This palace, rogether with its gardens and appurtenances, occupying in the whole an area of seven acres and twenty perches of land, was ceded by the representatives of the Montague family for the moderate sum of $£ 10,000$.

The necessary repairs (which, the house having stood long empty, proved very expensive) 
were immediately proceeded upon; and the proper book cases and cabinets having been completed, and the collections removed thither, and properly distributed and arranged, the Museum was, at length, opened for study and public inspection, on the 15th of January, 1759.*

\section{II.}

\section{GRADUAL INCREASE.}

1. $-B Y$ ROYAL AND PARLIAMENTARY GRANTS.

This establishment ranks the Sovereigns of these Kingdoms among its first and most munificent benefactors.

His late Majesty, fully impressed with a conviction of the utility of this Institution, was, in the year 1757, graciously pleased to make over to this trust, the whole of the very choice

and

* Besides the $\mathscr{R} 20,000$ paid for the Sloanean, and the \&10,000 for the Harieian, collections, and $£ 10,000$ for Mnntague House, the sum of $228,663.15$ s. was laid ont in the purchase of $£ 30,000$ three per cent. Reduced Annuities, and appropriated to the maintenance of the establishment: and the remaining 226,531. 3s. 2d. raised by the Lottery, scarcely sufficed to defray the expences of repairs, cases, furniture, remoring the collections, and various other incidental charges. 
and important library of printed books and manuscripts, which had been gradually collected by the Sovereigns of these Realms, from Henry VII. down to William III.; since whose time it has been continued, and is still annually increasing, by the privilege annexed to it of being supplied with a copy of every publication entered in Stationers' Hall. His Majesty was also pleased, at the same time, to transfer to the Museum, the reversion of the salary of $£ 300$ a year, annexed to the patent office of King's Librarian, which had been once held by the learned Dr. Bentley, and afterwards by his son; who transferred it to Claud Amyand, Esq., by whom it was retained till his decease in the year 1775 .

Besides the books immediately collected by the Sovereigns, and principally by Henry VIII., from the opportunities which offered at the dissolution of the munasteries, this collection, which, at the time when the Museum Act passed, consisted of about 2000 MSS, and upwards of 9000 printed books, contains the library of Archbishop Cranmer, and those of Henry Fitzalan Earl of Arundel, and his sonin-law Richard Lord Lumley, of Sir John Morris, and of Isaac Casaubon; some of the volumes 
volumes of the latter, deriving additional value from the MS. notes of the learned proprietor. This library also contains, among other nost valuable articles, the venerable Alexandrian Codex of the Bible, several splendid MSS. chiefly biblical and chronicles; and amoing the printed bonks, abundance of old and rare editions, many of them being presentation copies to the Sovereigns from their respective authors.

His present Majesty, equally desirous to contribute to the enlargement of an institution so GEOREE IIT. Collection of Pampulets. useful and ornamental to his dominions, availed himself of an opportunity, which occurred soon after his accession, of making a very ample, and in an historical point of view, a most valuable addition. A numerous collection of pamphlets and periodical papers, published in the convulsive interval between the years 1640 and 1660 , after having passed through the hands of various persons, some of whom were, at times, obliged to secrete it with uncommon care and circumspection, was at length offered for sale in the year 1762 ; and His Majesty, being apprized of the circumstance, immediately ordered the same to be purchased and to be deposited in the $\mathrm{Mu}$ seum. The collection consists of upwards of 
30,000 articles, bound in about 20 no volumes; most of the tracts being now becoine uncommonly scarce, and many of them probably unique.

Antiquities, $\mathscr{F}^{\circ}$. This establishment is also indebted to the munificence of the same gracious Sovereign for a considerable collection of antiquities, and some natural productions, chiefly Egyptian, and an ong them one of the finest Mummies perhaps now in Europe, which were sent to the late Earl of Bute by Edward Wortley Montagu, Esq., and presented by the former to His Majesty, who was pleased to transfer it to the Trustees of the Museum.

Lettery Fickels. His Majesty, likewise, in the year 1761, granted to the said Trust a number of Lottery Tickets which belonged to his Royal Predecessor, containing prizes to the amount of $£ 1,123$; which sum has since been incorporated with Major Edwards' fund, and thereby applied to the further increase of the Repository.

Journals of Parliament.

In 1773 , a complete set of the Journals of the Lords and Commons, together with their several indexes and reports, was sent to the Museum by his Majesty's command. Several other 
other Royal Donations, though not of such extent as those just mentioned, must not, however, be here altogether omitted: such are a collection of Natural and Artificial Curiosities from the N. W. Coast of America, brought home, in 1796, by Mr. Menzies; and several single books of great value and utility.

Lastly, our army in Egypt having acquired, by the capitulation of Alexandria in 1801, many articles of Egyptian antiquities, which had been selected and shipped with a view of being transported to France; these acquisitions were sent to England in 1802, and were imme. diately ordered by his Majesty to be placed in the British Museum.

The number of antiquities contained in the

Museum was originally so inconsiderable as rian Collection scarcely to deserve any particular notice; but this deficiency was amply supplied when, in the year 1772, the admirable collection of Sir William Hamilton, K. B. was added to the Repository. Sir William Hamilton having, during a long residence at Naples as his Majesty's Envoy, had many favorable opportunities of acquiring a great number of articles of Greek and Roman antiquity, particularly the largest store then

South Sea Curiosities.

Egyptian Antiquities.
Partiament 
known of ancient vases, usually, though erroneously, called Etruscan, caused the whole collection to be brought to England; and having afforded an opportunity to a Committee of the House of Commons to inspect the same, and to satisfy themselves as to its real value and importance, the House, upon the report of this committee, voted the sum of $£ 8,400$ to Sir William Hamilton for the purchase thereof, in order to its being deposited in the Museum for the use of the public. It will be needless to point out to those, who, being conversant with the arts, may have opportunities of inspecting this addition, how much it has contributed, and will, no doubt, still contribute, to the improvement of the national taste; the contrast between the present and the former style, in all our manufactures in which the finer arts are concerned, being too obvious to be here particularly insisted upon. The Public is also largely indebted to Sir William Hamilton for many liberal and repeated donations which he has, from time to time, conferred on the Museum, not only in addition to the above collection of antiquities, but also in abundance of articles of natural history, particularly of the volcanic productions of Mount Vesuvius, of which he has, perhaps, been the most careful observer since the days of Pliny. 
An opportunity having presented itself, in the The Townleian year 1805, of acquiring a large and exquisite collection of Greek and Roman statues, busts, and other sculptured marbles, formed by Charles Townley, of Tuwnley, in the county of Lancaster, Esq. at a great expense, during a course of many years, and by frequent journies to Italy, Parliament, with a liberality well becoming so great a nation, cheerfully granted the sum of $£ 20,000$. (at which it was estimated by persons well acquainted with the value of such articles), and ordered it, in like manner, to be preserved in this Repository.

The original building being, by no means, sufficiently spacious for the reception of this and Open to Siudents and the Egyptian collections, Parliament has, from time to time, voted sufficient supplies for the purpose of erecting an additional edifice, which is now completed; and a magnificent collection of ancient sculptures is, at length, opened for the inspection of strangers, as well as for the improvement of artists, an advantage which the students in the fine arts have never before enjoyed in this country.

Parliament, ever ready to avail itself of every opportunity for extending the utility of this In-

The Lansiour Manuscripts.

$$
\text { c } 2
$$

stitution, 
stitution, has recently accepted an offer, made by the executors of the late Marquis of Lansdown, for the purchase of his valuable collection of manuscripts, and to add it to the several copious libraries of the same nature already in the Museum. The vote, for this purpose, passed in the year 1807 ; and the sum granted, according to the best valuation that could be made, amounted to $£ 4,925$. Its merit, very similar to that of the Cottonian Library, consists chiefly in original and authentic documents relating to the history of England, particularly during the reigns of the Tudors; besides a number of Collectanea of a miscellaneous nature, made by several eminent statesmen and learned antiquaries.

Greville's Minerals.

An opportunity having presented itself in the course of the year 1810, of acquiring the extensive Collection of Minerals formed by the late Right Hon. Charles Greville, the Trustees, in a Petition to the House of Commons, recommended the purchase thereof, for the use of the public. A committee was accordingly appointed, who, having deliberated on the subject, and taken the depositions of the most eminent Mineralogists they had the means of consulting, reporsed the opinion of these referees as follows: or That they considered the entire Collection to be 
"s equal to most, and in many parts superior to " any other similar Collection, which any of "them have had opportunities of viewing in of this and other Countries: and that, upon "accurate examination, they had estimated the "value of it at $£ 13,727$." - This sum was accordingly voted, and preparations are now in great forwardness for exhibiting the most ostensible part of the Collection in the great Saloon.

Thus far have we commemorated the munificence of our late and present most gracious Sovereigns individually, and of the Legislature collectively, towards establishing and extending this national Institution, which will, no doubt, be allowed to reflect great honour upon the country at large, and from which men of letters, artists, and even mechanics of all descriptions, have derived, and continue to derive, most essential advantages in their respective pursuits. Our rext duty is briefly to state what the Trustees, in their corporate capacity, have effected towards the further increase of the esta. blishment committed to their care. If in recording their various acquisitions, we have not objects 
objects of such magnitude to notice as those above specified, yet some, it will be allowed, are by no means of trivial import; and it must moreover be observed, that not only the fund at their disposal for these purposes is very limited, but that a great part of it is necessarily expended from time to time in the purchase of singie books, and other separate articles, which occasionally present themselves for sale, and which, however important, are yet far too numerous to be here specifically described.

It might well be expected, that in consequence of the great progress made of late years.in the science of Natural History, the collection of Sir Hans Sloane, which, when it was purchased, was deemed of the first magnitude, would insensibly become retrograde in its comparative value: and this in fact was found to be particularly the case in the classes of Ornithology and Mineralogy. Accordingly, in order to supply the former of these deficiencies, the Trustees being, in the year 1769, informed that a large collection Grenwood's of stuffed Birds, in uncommon preservation, had Birds. been brought over from Holland by a person of the name of Greenwood, who, having for a time exhibited them to the public, became desirous to dispose of them at a reasonable price, they readily 
readily availed themselves of the opportunity, and purchased the whole for the sum of $£ 460$. Many additions were afterwards made by purchase and donation: and the aggregate soon formed, not indeed a complete, but as extensive and curious a collection as any perhaps at that time extant.

In the year 1798, a favourable opportunity presented itself for supplying the deficiency in the Mineralogical part of the Repository. Charles Hatchett, now of Roehampton, Esq., having, during his travels in various parts of Europe, formed a large and well chosen collection of $\mathrm{Mi}$ nerals of every class, which the Trustees learnt that he was not unwilling to part with on reasonable terms, they accordingly made him an offer, and the agreement was concluded for the sum of $£ 700$; and all that was valuable of the Sloanean Collection having been incorporated with this ample accession, the whole, with the addition of what Mr. Cracherode's bequest has since supplied, may be said to form, if not a splendid, at least a very copious and useful mineralogical collection.

All those who are conversant with Oriental Literature, must be well acquainted with the

Hatchett's Minerals. 
distinguished merits of the Editor of the Gentoo Code of Laws in that branch of erudition, and be aware that a collection of Indian Works, made by such a man, cannot but be an object of intrinsic value. Accordingly, the Trustees having received intelligence that the Oriental Library. of Nathaniel Brassey Halhed, Esq., might be obtained at a reasonable price, did not hesitate to make the acquisition; and, in the year 1796 , obtained the whole of it for the sum of $£ 550$. It consists of ninety-three volumes, fourteen of which are in the Shanskrit language, and the rest chiefly Persian: and to these have been added twenty-six volumes recently purchased of the Executors of the late Colonel Hamilton, the Translator of the Heydaya, and the four Vedas in the Shanskrit language, presented by Colonel Polier; besides thirty-two volumes which came with the trophies of our Egyptian expedition, and various other curious and valuable articles.

Tyssen's

Samuel Tyssen, Esq. who, during a short, but Saxon Coins. active life, had spared neither labour nor expense in accumulating a collection of Coins of uncom. mon magnitude, upon his death, in the year 1802, left this immense treasure to be disposed of by his executors, in any way they should deem most eligible. Among the rest was found 
in this collection the most complete series of Saxon coins perhaps in this Kingdom, and for this the Trustees made an offer of $£ 620$, which was accepted, and the whole is now incorporated in, and adds no small importance to, the very extensive numismatic collection, which was already deposited in the Museum.

In the year 1807, an offer was made to the Trustees to purchase a collection of ancient Classics which had been in the possession of the celebrated Dr. Bentley, and contained a great number of his truly learned illustrations and remarks. The Trustees, well aware of the intrinsic value of this accession, ordered the payment of $£ 400$, the sum demanded, and caused the collection to be added to their Library. It consists of eighty-four volumes, among which is Dr. Bentley's copy of the plays of Aristophanes, with his copious and profound illustrations, a commentary much prized by the first critics in Greek literature.

The Trustees having, at all times, particularly at heart to make such additions to their ample Roberts's English Coins. stores as may tend to illustrate national objects of inquiry, did not fail to listen to a proposal made them, in the year 1810 , by Edward Roberts, Esq.

Dr. Bentley's Classics. 
of the Exchequer, offering them the purchase of a rich series of the Coins of the Realm, from the Conquest to the present time, which he valued at 4000 guineas.-Having, on sufficient evidence, ascertained the importance of the object, and the fairness of the estimate, they accepted the of fer, by which means, with the addition of the Saxon coins just now mentioned, and those of subsequent dates alrearly in the repository, they may safely boast of being possessed of the most complete national collection of coins now extant.

\section{3.-DONATIONS BY TRUSTEES.}

In enumerating the multitude of additions made to this repository by private donations, it is but just to distinguish those benefactors, who besides gratuitously bestowing much of their time and attention to the concerns of the Museum as Trustees, have likewise enriched it by repeated and valuable gifts, which they have, from time to time, presented, either singly, or in collective, and in some instances, in considerable numbers.

The Rev. Thomas Birch, D.D. many years Secretary to the Royal Society, and one of the fifteen elected Trustees of the first nomination, after having rendered great services to the Institution, 
tution, while in its infancy, by his unwearied assiduity and exertions, closed a meritorious life in the year 1766, bequeathing his whole, not indeed very numerous, but yet truly valuable library, to the Museum; and the annual produce of all his property in the funds, amounting to £522. 185. New Suuth Sea Annuities, to be equally shared among the three Under Librarians for the time being. This learned divine having chiefly distinguished himself as a biographical writer, his library excels particularly in books relating to that branch of literature; ard among his manuscripts are several collections of historical documents, correspon. dences of men of note, and copies of various State Papers, which he obtained from persons in high stations, with whom he lived in habits of familiar intercourse,

In the year 1765, Gustavus Brander, of Christ Gustavus BranChurch, in Hampshire, Esq., made a considerable der, Esq. addition to the Museum, by the donation of his fussils, chiefly collected by himself in Hampshire, of which a classical catalogue was drawn up and published by his friend and countryman, Dr. Solander, and to this he afterwards added many valuable donations of the same nature. 
Thomas Tyrwhitt, Esq.

Thomas Tyrwhitt, Esq., a gentleman whose name will ever be revered, as long as true taste and learning are held in estimation, was pleased to bequeath to the Museum all the books in his select library, which were not already in that Repository; by which means about nine hundred volumes, chiefly classics, were, in the year 1796, added to the collection. And soon after, in the year 1800, his example was followed by Sir WilSir William liam Musgrave, Bart., who, by a similar bequest, Musgrave. enriched the Museum library with near two thousand volumes of printed bouks, among which are a great number of biographical tracts, many of them of great rarity and curiosity; and about forty volumes of manuscripts, the greater number of them being an obituary kept by himself, during the whole period of his active career.

The Cracheroieancollection.

For the greatest, and though not the most conspicuous, yet no doubt the most valuable of the accessions by gift, the public is indebted to the spontaneous and splendid munificence of a private individual, upon whom, were this a place for panegyric, the greatest encomiums o ight in justice to be bestowed. The Rev. Clayton Mordaunt Cracherode, M. A.; a gentleman equally eminent for knowledge, taste, and urbanity, had, during the whole course of his 
too limited career, employed his time, talents and ample fortune, in forming numerous and choice collections of printed books, prints, coins and medals, minerals and shells. This treasure he, with a liberality of which there are few examples, was pleased to bequeath to the Museum, where, due preparations having been made for its reception, it was actually deposited in the year 1799. To enumerate only the most considerable articles of these collections would far exceed the limits of this introduction; but some idea may be formed of their importance, by the value set upon them by experienced dealers in the different branches, when the House of Commons called for such an estimate, with a view to remit the Legacy-tax upon the whole bequest.*

To this list must be added, the name of the Right Hon. Sir Joseph Banks, Bart, K.B.,

Sir Joseple Banks. who

* This valuation is as follows:

Printed Books. $£ 10,000$

Coins and Medals 6,000

Prints 5,000

Shells and Minerats 2,000

Gems 500 
who, after his return from his circumnaviga. tion, deposited at different times in the Museum numerous collections of natural and artificial curiosities from the newly discovered islands in the South Seas, which, with considerable additions since made by the Admiralty, Captain Cook, and other officers who had performed similar distant and perilous voyages, forms now a very conspicuous part of the Museum. Among the many donations of various kinds which Sir Joseph Banks has since bestowed, and still continues to confer upon the Establishment, we must not omit to mention a large set of Icelandic books, both printed and manuscript, which he cullected in a voyage he made in the year 1772 , to that island. Nor can the public be uninformed of the indefatigable zeal he has ever displayed in his endeavours, as a Trustee, to advance the honour and advantage of this Institution, which, together with his many other exertions for the benefit of science, must ever rank him among her best friends and strenuous promoters.

Lastly, the mineralogical collection has of late received a valuable accession by the munificence of the Right Honorable Lord Grenville, who was pleased to present the Museum with a series 
of Peruvian ores, consisting of nearly 200 articles.

\section{BENEFACTORS NOT TRUSTEES.}

Before we proceed to the names of private benefactors not Trustees, we must here gratefully acknowledge the liberality of several Crowned Heads on the Continent, and many political as well as literary bodies, who have, from time to time, been pleased to contribute to the increase of this Institution. As to the former, the Museum may boast of various benefactions, chiefly in books, from the Emperors Francis $\mathbf{I}$. and II. and the Empress Maria Theresa, from Catherine II. Empress of Russia, from Pope Pius VI. and their Majesties Charles III. King of Spain, and Frederick V. King of Denmark, Among our own public offices, it has repeatedly received additions from the Admiralty, the War Office, the Board of Longitude, and the East-India Company: and as to the Literary Societies which regularly send in their various periodical and other publications, we are bound to make honorable mention of the Royal Society, * the Society of Antiquaries, the

Society

* In the year 1781, this Society presented the greatest part of its collection of Natural and Artificial Curiosities to the Bntish Museurr. 
Society for the Encouragement of Arts and $\mathrm{Ma}_{\mathrm{a}}$ nufactures, the Universities of Oxford, Cambridge, and Leyden, the Imperial Academy of Brussels, the Royal Academy of Lisbon, the Colleges of Physicians of London and Edinburgh, the Faculty of Advocates of Edinburgh, and several other learned bodies, whose donations have been no less frequent than valuable.

Col.Lethiullie:, $\& c$.

Among the multitude of private individuals, not members of the Trust, who have enriched these collections, and whose names and donations are carefully registered in a book kept for the purpose, we must here select, as being foremost in their liberality, three gentlemen of the same family, viz. Colonel William, Mr. Pitt, and Mr. Smart Lethiullier, who, so early as the year 1756 began their benefactions, and continued them for several years, thereby materially increasing the collection of Egyptian Antiquities, to which they added two mummies, and a great number of idols, utensils, and other implements.

Thomas Hollis, Esq.
The name of Thomas Hollis, of Corscombe, in Dorsetshire, Esq. appears perhaps more frequenily than any other in the list of Benefactors: he having, from the year 1756, to the day of his death in 1774, been unremitted in his contrio 
butions, consisting chiefly of rare books, prints, a variety of bronze idols, and various other productions of the arts.

The late Earl of Exeter ranks likewise very high in the register of Benefactors, not so much The Earl of Exeter. perhaps for the number of his gifts, as for their intrinsic value and importance. Among these are the bronze head of Homer, which he purchased at the sale of Dr. Mead's collection; a large, if not complete, set of the Roman As, and its divisions, and of Cotorniate Medallions; and a splendid collection of drawings by Mosman; being highly finished copies in black chalk of many of the most capital pictures in Rome, which accoiding to a moderate computation, could not have cost his Lordship less than $£ 3,000$.

We forbear to extend this catalogue any further, not for want of distinguisined names, whose donations have been numerous and valuable, but that we may not too far exceed the limits of an Introduction.

\section{III.}

CONSTITUTION, AND REGULATIONS, OF THE ESTABLISHMENT.

This extensive Repository, which in its aggreThe Trust: gate, and considering the number of objects it embraces, 
embraces, is perhaps equalled by few in the worid, is, as has been above observed, committed to the care of forty three Trustees.* These hold regularly quarterly General Meetings, monthly Committes, and annual Visitations, besides extrameetings of each description, according as exigencies may require. In these meetings are framed and enforced the bye-laws and the regulations for the government and preservation of the Institution; the expenditure of the funds are here ordered and controlled, and every precautionary step is taken for the safety of the buildings, and the proper application of the whole tor the intended purposes of public utility. Although. paramount in their powers, yet are they, from time to time, called upon by Parliament to lay before them statements of their accounts and various proceedings.

Establishment The establishment of Officers consists, at - Officers, \&c. present, of a Principal Librarian appointed by His Majesty, and of four Under and four Assistant

2 21 Oncial Trustees.

7 nomplnated by the representatives of the Sloane, Cotton,

Harley, and Townley Families; and

15 elected by the above Oficial and Family Trustees. 
Assistant Librarians, named by the three principal Trustees, the Archbishop of Canterbury, the Lord Chancellor or Lord Keeper, and the Speaker of the House of Commons. Each Under Librarian, jointly with one of the Assistants, is particularly charged with the care of one of the departments of wbich there are four, namely, 1. the Library of Printet Rooks: .2 the Library of Manuscripts ; 3. the Department of Natural History and Modern Artificial Curiosities; and 4. the Department of Antiquiries, Coins, Drawings, and Engravings. 'The duties of these offcers are to arrange and keep in order the several collections committed to their charge, to correct the old, and when required to compile new catalogues of their contents, to pay proper attention to visitors of distinction, either for rank or learning, and some of them, in rotation, to attend the Reading. Room, which it is strictly ordered should never be left without an inspecting officer. Besides these, a Secretary, a Surveyor, five ordinary and eight extra Attendants, a Messenger, a Porter, a Gardener, and a few inferior servants complete the establishment.

The chief use of the Museum consists, no doubt, in the means it affords to men of letters The Reading Room. and artists to recur to such materials as they may 
want in the prosecution of their studies or labours. For this purpose a very commodious apartment has been set aside, by the 'name of the Reading-Room, which is open every day, Saturdays and Sundays excepted, and to which persons not wholly strangers are freely admitted, and there readily supplied with whatever books, or manuscripts, they may desire to con sult; as also with such productions of art or nature, of which they may wish to have a closer inspection than can be had in the cursory manner allowed to ordinary visitors.

The regulations made for the proper use of this privilege are found fully adequate for the intended purpose; and the intentions of the Trustees that, as far as is consistent with the security of their important charge, every facility be afforded to those who wish to arail themselves of this part of the Establishment, are fulfilled with promptness and fidelity.

Admission of Strangers:
For the admission of companies to a sight of the Museum (a popular, though far less useful application of the Institution) various regula. tions have, from time to time, been formed, every successive alteration having had for its object to add to the facility of access, and in every respect 
to the accommodation of the public. According to the present regulations, the Museum is open for public inspection, on the Monday, Wednesday, and Friday, in every week (the usual vacations excepted*), from ten till four o'clock, and all persons of decent appearance who apply between the hours of ten and two, are immediately admitted, and may tarry in the apartments, or the gallery of antiquities, without any limitation of time, except the shutting of the House at four o'clock. Artists who are properly recommended, especially by a professor of the Royal Academy, are also allowed to draw from the Antique Marbles, or any other objects on which they may choose to exercise their skill. In general, every practicable facility is afforded that may render this Institution really useful to science and the arts, for which it is chiefly intended, as well as gratifying to the curiosity of the multitude, who incessantly resort to it in quest of amusement,

IV.

- The Christmaa, Easter, and Whitsun Weeks, on Thanksgiving and Fast-days, and during the months of August and Sep. tember, 


\section{IV.}

\section{DISTRIBUTION OF THE COLLECTIONS.}

The whole of these accumulated treasures are at present arranged in thirty-eight rooms, of the contents of which the following are the general titles :

\section{Lower Floor.}

Rooms

Page

I.-XII. Library of printed Books

\section{Upper Floor.}

3. Modern Works of Art ............... 3

II. The Reading Room .............. 4

III. Lanstown Manuscripts.............. 4

IV. Sloanean and Birch's Manuscripts......... 5

V. Harleian Manuscripts $\ldots \ldots \ldots \ldots \ldots \ldots 6$

VI. Harleian MSS. and additions............. 6

VII. Royal and Cottonian MSS............ 9

Grand Saloon, Minerals.............. 10

VIII. Minerals...................... 11

IX. Shells, Fossils, and Herbals........... 27

$\mathrm{X}$. Insects, Worms, Corals, and Vegetables ... 32

XI. Birds and Quadrupeds, stufied .......... 36

XII: Quadrupeds, Snakes, Lizards, and Fishes, in spirits ..................... 41 


\section{Gallery.}

Rooms

I.

Terra Cottas ....................43

II. Greek and Roman Sculptures $\ldots \ldots \ldots \ldots \ldots 52$

III. Ditto ..................... 54

IV. Greek and Roman Sculptures .......... 59

V. Roman Sepulchral Antiquities ...........60 60

VI. Greek and Roman Sculptures ........... 65

VII. Roman Antiquities................ 75

VIII. Egyptián Antiquities ................ 76

IX. Ditto ..................... 78

X. Greek and Roman Sculptures .......... 84

XI. Coins and Medals ................. 92

XII. Sir William Hamilton's Collection ........ 96

XIII. Drawings and Engravings .............. 100

Ante-Room, Portland Vase $. . . \ldots \ldots \ldots \ldots \ldots . . . .64$ 
** The Public are apprized, that the following come pendious Synopsis is merely intended for persons who take the usual cursory view of the Museum. The several $O_{\text {ficicers }}$ have been some time employed in preparing scientific Catalogues of the Contents of. their respective departments, which, from the great extent of the Collections, musi necessarily take up much time, and, when completed, will of course be very voluminous. 


\section{S Y N OPS I S, $\xi c$.}

ON entering the gate of the Museum, a spacious quadrangle presents itself, with an Ionic colonnade on the south side, and the main building * on the north; the two wings being allotted for the dwellings of the Officers. The Architect, Peter-Puget, a native of Marseilles, and an artist of the first eminence in his time, was sent over from Paris by Ralph, first Duke of Montagu, for the sole purpose of constructing this splendid Mansion.

\section{GROUND FLOOR.}

LIBRARY'OF PRINTED BOOKS.

The tirst finor, consisting of twelve rooms, contains the Library of Printed Books. Stran-

LIBRARY of Printed Boors. gers are not conducted through these apartments, as the mere sight of the outside of

books

* This building ineasures 216 feet in length, and 57 in height, of the top of the cornice. 
LIBRARY OY
PRINTED Boozs. books cannot convey either instruction or

The companies, on being admitted according to the regulations, are immediately conducted up the great staircase, the decorations of which have been lately restored. The paintings on the ceiling, representing Pbaeton petitioning Apollo for leave to drive his chariot, are by Charles de la Fosse, who, in his time, was deemed one of the best colourists of the French school; and of whom there are many valuable performances in France, among which are the paintings on the cupola of the dome of the Invalids, which are ranked among the admisanda of Paris. The landscapes and architectural decorations are by James Rousseau, whose particular skill in perspective has, at all times, been held in high estimation.

UPPER

* An Alphabetical Catalogue of this Library was printed in the year 1787, in two volumes folio; but as great accessions have been obtained of late, this Catalogue is now under revision asd a new elition, greatly enkarged, is in the press. 


\section{UPPER FLOOR.}

\section{FIRST ROOM.}

MODERN WORKS OF ART.

From the great staircase strangers are conducted into the first room of the Upper Story, containing a miscellaneous collection of modern ROON 1 .

WORKS OE $A R$ T. works of art, from all parts of the world. The ceiling of this room, representing the fall of Phaeton, was painted by La Fosse. The contents are arranged as near as possible in a geographical order, as follows:

Cases.

Europe. .................. I. to IV. Asia .................. V. to $V I I$. Africa................... VIII. South America.................... East Coast of North America...........X. West Coast of North America.... XI. to XIV. Otaheite.................... to XVIII. Sandwich Islands and Marquesas

XIX. to XXII.

Friendly Islands....... XXIII. and XXIV. New Zealand..........XXV. and XXVI. Various small articles, in two tables. 
ROOM I.

WORKS OF

ART.

This collection, the greatest part of, which consists of donations, not being strictly of a scientific nature, no further detail is here given of its contents.-In making the selection that is here exhibited, from a large store of similar materials, deposited in a less conspicuous part of the house, a preference has been given to such articles as may best serve to illustrate some local custom, art, manufacture, or point of history; but many even of these will gradually be set aside, to make room for others of more intrinsic value.

\section{SECOND ROOM.}

ROOM II.

This and the two next rooms are appropriated for the use of the readers.

DEPARTUENT OF MANUSCRIPTS.

\section{THIRD ROOM.}

\section{LANSDOWN LIBRARY OF MANUSCRIPTS.}

ROOM III.

This library, which having been lately acIansdown quired is not yet finally arranged, consists of
Mss. 1352 volumes, of which 114 contain an ample collection of Lord Burleigh's State Papers, many 
of them originals : 46 volumes of Sir Julius ROOM III. Casar's papers, all relative to the history of the time of Queen Elizabeth and King James I.: Lansilown MSS.

108 volumes of historical collections of Dr. White Kennet, Bishop of Peterborough : a considerable number of original, royal, and noble letters and papers; and a great store of historical, juridical, biographical, heraldical, and miscellaneous collections.*

\section{FOURTH ROOM.}

SLOANEAN AND BIRCH'S COLLECTIONS OF MANUSCRIPTS.

A collection of MSS. bequeathed by the late RoOM IV. Dr. Birch, consisting of 337 volumes, chielly on history, biography, divinity, and literature. (Vide Introduction, p. xxii.)

Three Presses between the windows.

Birch's MSS.

Sir Hans Sloane's library of MSS. consisting of Presses III. 4100 volumes, principally on physic, natural Sloanean MSS. history, and natural philosophy. It also contains Kæmpfer's MSS, ; several journals of voyages; and sume oriental MSS.

In a recess, within this room, are placed $\mathrm{Mr}$. Halhed's and some other collections of oriental G

MSS.

* The repertory to this library being, at present, nothing more than a site catalggue, and, of course, very imperfect, will require to be newly constructed on the enlarged plan of the other catalogues belonging to this Institution. Some progress has been made in this work; but it must be some time before it can be completed. 
soom IV. MSS.: (vide Introduction, p. xix.) A collection MSS. of MSS. and rolls, consisting of 62 articles relating to Kent, purchased of Mr. Hasted: and someselectMSS. out of the other libraries in the Museum.

Over the chimney is a drawing of the palace of Colomna, near Moscow, which belonged to the Czars of Moscovy; it was built of wood, and is now demolished. Presented by the Honorable Percy Wyndham.*

\section{FIFTH ROOM.}

TOOM V。

The greatest part of the Harleian Library of Manuscripts is deposited in this room.

\section{SIXTII ROOM.}

noou vi. The remainder of the Harleian Library of Manuscripts is deposited in this room. Also MANY

* A catalogue of the conients of this Room, and of most of the additional acquisitions in the fifth Room, compiled by the Rev. S. Ayscough, was printed in the year 1792 , in two rolumes quarto.

+. A compendious view of the arrangement of this Library is printed, and may be had, together with the Analytical Syllabus of the Library of Printed Books. A catalogue of these MISS. was printed in the year 1759 , in two volumes folio; but the latter part of it was found so defectire, that it became necessary to hare it corrected and enlarged. This improved work is now completed, and, with copious Indexss, fornio four volumes follo. 
BIANY ADDITIONS BY GIFT, BEQUEST, AND PURCIASE.

AMONG WHCII ARE PARTICULARLY REMARKABLE,

Fifty-seven volumes, containing a series of public acts relating to the history and govemment of Roov V1. England, from the year 1115, to 1608, collected by Thomas Rymer, but not printed in his $\mathbb{F}$ cdera; and sixty-four volumes of rolls of Parliament: the whole ordered to be deposited in the Musenm, by the House of Lords.

A collection in forty-seven volumes, rolating to the history of Ireland; presented by the Rev. Jeremiah Milles, Doan of Excter.

Forty-three volumes of Icelandic Nanuscripts: presented, with a much more numerous collection of printed books, by the Rt. Hon. Sir Joseph Banks, Bart. K. B.

Forty-one volumes, containing the decisions of the commissioners for settling the City estates after the fire of London : presented by Thomas Cowper, Esq.

Twenty-four volumes relating to the history of Music, which, tegether with a considerable colJ ction of printed books on the same subject, were bequeathed by Sir John Hawkins.

Twenty-seven volumes of music, chiefly mot. tets, and other church music, by old composers, (Prenestini, Palestrina, Pergolese, Steffani, Handel, \&c.) bequeathea by James Mathias, Esq.

$$
\text { a } 2
$$

Thirty-eight 
Thirty-eight volumes of manuscripts, and nine of drawings, being a copious collection towards a topography and history of the county of Sussex: bequeathed by Sir William Burrell.

Forty four volumes, 32 of which contain an obituary kept by the donor, and the rest, being a collection of autographs, original warrants, and other documents, catalogues of portraits, \&c. bequeathed, together with a considerable library of printed books, by Sir William Musgrave, Bart. (Vide Introduction, p. xxiii.)

A numerous collection of manuscripts, chiefly relating to the county and University of Cambridge, bequeathed by the Rev. William Cole, M. A.

In the presses $\frac{2}{1}$ and $\mathrm{XVI}$. are two rolls of the Pentateuch on vellum, the former of considerable antiquity, and the latter much more recent: this latter, together with a considerable number of Hebrew MSS. and printed books, was presented by Solomon da Costa, Esq.

Against the press $\frac{2}{I}$ hang three specimens of minute writing, forming the portrais of Queen Anne, Prince George of Denmark, and the Duke of Gloucester their son.

Against the press XVIII. hangs an original deed in Latin, written on Papyrus, being a conyeyance of some land to a monastery; dated 
Ravena, Ao. 572, bought at the sale of the Pinelli library. And opposite to it is a large ROOM VI. specinen of the reed (Cyperus Papyrus) of which that kind of paper is made.

In the second window hangs an Italian note to Sir William Hamilton, written on modern papyrus, explaining the mode of preparing it.

\section{SEVENTH ROOM.}

THE ROYAL LIBRARY OF MANUSCRIPTS.

Deposited in XXXIII Presses.

THE COTTONIAN LIBRARY OF MANUSCRIPTS.

Deposited in XXI Presses.

These two libraries are not classed in a strict RoOM VII. scientific order *

MSS.

In the press under No. XIX of the Cottonian library are deposited ninety-four volumes of extracts, transcripts, and notes, chefly relating to the Exchequer, collected by Thomas Maddox,

Esq.

* Of the King's Library, a catalngue compiled by Mr. David Casley was printed in the year 1734, in quario: and of the Cottozian Library, there are no less than three catalogues extant : the first by Dr. Thomas Smith, printed 1696, folio; the second, being an attempt towards a classical arrangement, printed in 1777, octaro ; and the third, improved and considerably eularged by Mr. Planta, printed by His Majesty's command, in the year 1802, folio. 
noom VIr. Esq. historiographer to Queen Anne and King Mss. George I. and bequeathed by his widow, as an addition to the Cottonian library.

On the table, in a glazed frame, is the original of the Magna Charta, bslonging to the Cottonian library; and on the side of it is a fac-simile engraving of it, by $\mathbb{P}$ ine.-Against press $\mathrm{XXI}$ of the Cottonian library is the original of the Articles preparatory to the signing of the great Charter, perfect with the seal; presented Anno 1\%69 by Earl Stanhope.

\section{THE SALOON.}

SALOON.

THE dome of this grand apartment was painted. by the above-mentioned La Fosse. It has generally been described as representing the A potheosis of Iris; but the most probable conjecture is, that the painter meant to exhibit the birth of $\mathrm{Mi}$ nerva. The landscapes and architectural decorations are by the same $J$. Rousseau who painted in the staircase: and the garlands of flowers are by John Baptist Wonoyer, the most eminent fower painter of his time. Over the chimney is a full length portrait of King George II., by Shackleton. This apartment is to contain the consolidated mineral collections of the Muscum. 
DEPARTMENT OF NATURAL HISTORY.

\section{EIGHTH ROOM.}

\section{MINEMALS.}

This room contains, besides the miscellarcous Room VII. specimens in the cases round the room, the NAT. Hist. Cracherodean collection, disposed in two tables, nearly in the Linnæan order: and a much more extensive series, arranged according to Werner's system of mineralogy, in 210 drawers in the imposts round the room. The whole of them will form part of the great collection now under arrangement in the Saloon.

THE CRACHERODEAN COLLECFION.

(Division 1.) Various earths, belonging to the TABLF argillaceous, talcose, and calcareous genera : variegated clays, fullers' eart?, \&c.-Carbonats of lime; double refracting epar ; variously modified crystallizations: nail-head spar; \&rc. rhomboidal sandstone from Fontainbleau; fibrous limestone: stalactites; kalk-sinter; peastone; the white and blue branched Flos ferri, \&xc.; arragonite ; brownspar.

(Div. 2.) The Tophus turbinatus, Livn. Trall. 
Roом vir. - several varieties of compact limestone (marMar. Hist. bles) : Cottam marble; Stirian shell or lumachella marble; Tiree marble; dolomite; fluor spar from Derbyshire, Durham, \&c. ; compact and fibrous gypsum; silenite.

(Div. 3.) Gypsum, selenite, \&c. ; compact and lamellar barytes, \&c. : strontian; boracite. Labrador spar; common feldspar: amazone stone. Adularia: Prehnite; rock crystals, amethyst druse with harmotome; finis drused with small rock crystals, \&c.

(Div. 4.) Rock crystal : topaze coloured, smoky, \&c. ; Bristol diamonds ; rock crystals, including various substances, as chlorite, rutile, \&c.; quartz crystals, on fiuor; \&c.; hacked quartz, rose quartz; feldspar and quartz avanturine; amethysts; flexible sandstone; perfect prisinatic crystal of emerald, inbedded in calcareous spar; sapphires and other precious stones in rings, \&c. Garnets loose and bedded in gneiss; steatite, \&c. Vesuvian, commonly called volcanic hyacinth. A rough diamond. Beryll, called aquamarin, shorl-beryll, Saxon and Brazilian topazes. Axinite or thumerstone. Chrysoprase. Actinote; tremolite, \&c.

(Div. 5.) Heliotrope, called also bloodstone; Egyptian jasper, known by the name of Cailloud'Egypte or Egyptian pebble; striped or ribband 
jaspers; porcelain jasper, \&c. Scotch and other ROOM VII. plain and striped lints, cut and polished. Precious Nat, Hist. opal of brilliant colours, disseminated in a dissolved porphyritic mass: semi-opal: variety vulgarly called Oculus mundi, becoming transparent when immersed in water (a polished oval piece in a case); common opal. Pitch stone: tuberose stone or menilite, from Menil Montant, near Paris, where alone it has hitherto been found. Woodstone or petrified wood (in one of the specimens the pores are completely preserved: Calcedony in stalactical and other forms : an egg-shaped piece of calcedony, containing water (enhydros); cacholong, or calcedony in a state of decomposition, \&c.; carnelians : a druse with red quartz crystals; a case with rings of mocca stones, \&rc.

(Div.6.) Various agates: jasp-agates, fortification agates, onychine agates, moss agates, \&c. Mealy zeolite; mesotype, stilbite, analcime, cubicite, \&c. cross stone (Harmotome). Large oval piece of azure stone (lapis lazuli).

(Div. 7.) Soapstone or steatite : a species of jade of which the Chinese carve figures and small ressels : nephritic stone, called axe-stone, from New Zealand, where the natives make hatchets, \&c. of it. Precious and common serpentine, diallage, smaragdite, \&c. Common or Venetian 
Room virr. talc, which enters into the composition of some NAT. Hist. cosmetics. Indurated talc: asbest, mountain flax, amianth, of which incombustible cloth may be made. Chlorite; mica; golden mica used for making artificial avanturines; mica mixed with some quartz, with feldspar: granite, \&c. Several varieties of porphyry.-Fossil salts, native rock salt, white in cubes, blue and red; iron and copper vitriol-Inflammable fossils : large specimen of native sulphur covered with selenite crystals, volcanic sulphur, \&c. Mineral pitch, elastic and slaggy; asphaltum; jet; cannel coal, \&c.

(Div. 8.) Various pieces of light and dark yellow anber, some of them including insects.Metals. Apple-green micaceous uran ore. Tungsteen; wolfram. Compact and radiated grey. manganese, stalactical and botroidal; earthy Inanganese. Native antimony; radiated grey antimony ore ; irridescent needle antimony ; needle antimony incrusted by stalactical calcedony ; white and bluish plumose antimony or feather ore; red antimony. Yellow, brown, and black blende, variously crystallized, in combination with galena, calcareous spar, brown-spar, pyrites, vitreous silver, \&c. on limestone, compact brown spar, fluor spar, \&c. ; calamine : botroidal, coating calcareous spar, \&c. Cobalt glantz; red earthy cobalt; cobalt bloom, \&c. 
(Div. 1.) Tin ores : several modifications of Room vil1. tin stone crystals; wood tin. Iron ores: mag- Nar. Hist. netic iron stone; several stecl-grey and tarnished TABLE varieties of specular iron (eisen-glantz) mostly 2. from the Island of Elba: micaceous iron (cubic oxide of iron of $\mathbf{M}$. de Bournon); red and brown ironstone (some with pavonine and gold tarnish; sparry ironstone; argillaceous iron: reniform or nodular ironstone, called eagle stone (one set in gold, used as an amulet): iron pyrites in variously modified crystallizations : small cubic pyrites on blackish clay slate, also known by the name of Irish diamonds; decomposed and liver pyrites; septaria. Copper pyrites and variegated copper ore.

(Div. 2.) Variegated copper ore: copper pyrites with opal, \&c. ; native copper, dendritical, laminar, \&c.; hæmatitiform and vitreous grey and red copper ores; earthy and irdurated copper azure in combination with malach te, copper green, \&c.; several varieties of malachite; arseniate of copper (olive ore), \&c.

(Div.3.) Arsenical ores: native arsenic (scherben cobolt); arsenical pyrites ; yellow orpiment : red orpiment or realgar. Copper nickel. Native bismuth : ar if ial crystallization of the same, by sudden conling of the melted metal. Silver ores : native silver, massive capillary, \&c.; silver 
POM vIr. in dendritical figures on a slab of black clay slate, NAT. Hist. probably a production of art; vitrcous and red silver ores. Lead ores: common galena, variously crystallized; compact galena : slickenside; brown, white, green, red and yellow lead ores; vitriol of lead. Quicksilver ores; dark and light red cinnabar, \&c.

(Div. 4.) Gold ores: native gold, massive, laminar, and filiform, in quartz, with needle-ore (bismuth sulfuré plumbo-cuprifère Haïy), \&c. Sylvan ore, or Tellurium. Platina in grains (in a phial).

Petrifactions, \&c. : impressions of fishes in lime. stone; glossopetræ, buffonites; insects : fossil crab; various echinites; shells : sevcral petrified species of pecten, chama, anomia; nautilus: belemnitæ, commonly called thunderbolts; cornua Ammonis; fragments of encrinitz, and pentacrinitæ, generally called star stones, \&c. ; petrified fruit of a palm, leaves of tropical ferns, \&c. in limestone.

$A$ collection of specimens of Roeks, arranged partly according to their natural affinities.

(Div. 5.) Granitic and other rocks belonging to the slate formation of Mr. Werner. Granites of the three usual constituent parts, (a fragment of the immense mass of granite con- 
veyed from the bay of Finland to St. Petersburgh, room virr. and now forming the base of the equestrian Nat. Histo statue of Peter the Great); granite in several stages of decomposition; new or regenerated grapite from the Hartz, \&c.; binary aggregates, called Granitels by some authors, (graphic stone from Scouland, Sweden); granite mixcd with other minerals, such as common shorl, garnets, actinote, chlorite, large polished pices of granitic rocks, some of them passing over into sienite and porphyry - gneiss of various approximation to granite on one side, and to micaceous shistus on the other; gneiss with garnets, shork, \&c.-micaceous shistus; the same approaching to gneiss on one hand, and clay slate on the other, (silvery variety of the latter used for roofing in Thuringia).

(Div. 6.) Continuation of the rocks constituting the slate-formation. Oldest or primitive clay slate of several colours; variegated (fruit or cuckoo) slate. Subordinate beds in clay slate: novaculite or whet slate, chlorite slate, drawing slate, better known by the name of black chalk; flinty slate and Lydian stone; anthracolite or kohlenblende. - Transition slate, mostly from the Hartz mountains, (a specimen, in which it is seen in immediate contact with grey wacke, a transition rock of the pature of old 
noom Vir. sandstone)-Grey-wacke, fine and coarse grainBAT. Hsss. ed and approaching to conglomerate, from the Hartz, where the metallic ores are principally found in it.-Fletz (secondary) rocks of this formation; sandstone; oidest sandstone with and without petrifactions; old red and white sandstine (Todliegendes of the German miners'; variegated sandstone, filtering stone; sandstones of large grained concretions passing over into conglomerates, to which, in point of external appearance, may also be referred some kinds of breccia and puddingstone (the beautiful Breccia verde d'Egitto composed principally of rounded pieces of a green hornstone, of granite, porphyry, \&c. in a mass which is itself a fine grained puddingstone).* As subordinate to the old sandstone formation are added some kinds of coal, together with specimens of slate clay (Fletz clay slate of some), generally forming the immediate roof of beds of coals ; slate clay with the characteristic impressions of vegetables, from Ilmenau in Thuringia, where it alternates with coal and sandstone; from Planitz, \&c.; common clay iron stone,

- The largest and most valuable monument now known to exist of this breccia is the Alexandrian Sarcophagus in the Gallery *f Antiquities of the Museum. 
stone, occurring in some coal formations, especial- RoOM vin. ly in England, with and without vegetable im- $\mathrm{N}_{A} \bar{T}_{*} \mathrm{H}_{15 \mathrm{~T}_{-}}$ pressions; roe stone, as subordinate to the variegated sandstone. - Some of the alluvial substances belonging to the slate formation; șand, clay, peat, \&xe.

(Div. 7.) Rocks belonging to the formations of serpentine, limestone and gypsum.-Older serpentine mixed with primitive limestone: serpentine from Zöblitz in Sasony, where it is manufactured into a variety of vases, chimneypieces, \&c.; newer serpentine, with steatite, amianth, garnets; with schillerstein (Diallage of Haüy .

Primitive limestone of various grain (large grained saline marble from Crodendorf, where it occurs in gneiss; very fine grained statuary marble from Carrara'; with mica; with tremolite. Red marble from the island of Tiree.-Grey and variegated transition limestone, principally from the Hartz; with petrifactions. - Alpine or oldest Fletz limestone: subordinate to it a kind of marl called Zechstein by the practical miners; bit minous marl slate, with copper, \&c. Gypsum; older Fletz gypsum : with boracite, arragonite; selenite; with swinestone, subordinate to this formation. Gypsum of later formation, with fabrous gypsum, clay, \&c. Seienite of very recent 
ROoM VIIr. formation from Montmartre. Rocksalt, consti$\mathrm{N}_{\mathrm{AT} \text {. Hist. }}$ tuting a formation nearly related to that of gypsum.

(Div. 8.) Containing porphyry, sienite and the trapp formation.-Hornstone porphyry, from Scotland, Norway, 'Thuringia, Egypt, \&c. (Egyptian antique porphyry with reddish grains of feldspar); porphyry with hornblende, with quartz veins; variety with its base less hard, being the jasper porphyry of some mineralogists : feldspar porphyry from Frauenstein. Clay porphyry; the same, with the feldspar in several stages of decomposition; with mica (the $\mathrm{Sa}$ sum metalliferum of Baron Born, being the principal repository of gold and silver ores in Lower Hungary and Transylvania): pitchstone porphyry; porphyry balls; porphyry breccia or Trümmer-porphyry.-Porphyry slate.

Sienite: (fragment of an Egyptian idol, composed of much hornblende, reddish feldspar unequally distributed, and some mica: being the true Signites of Pliny); similarly grained, without mica; with quartz (bianco e nero d'Egitto): porphyritic sienite consisting chieffy of hornblende appearing to pass over into hornblende slate.-Common hornblende rock. - Hornblende slate.-Greenstone. - Grcenstone porphyry: porfido verde antico, or serpentino verde antico, 
as it is sometimes erroneously called.-Basalt; RoOM virr. with olivine, zeolite, calcareous spar, \&c.- NAr. Hisr. Wacke, variolite, (toadstone), - Amygdaloid, \&c.

Meteroric stones: one of those that were seen to fall from the atmosphere, with many others, at Aigle in France; a fragment of one that fell at Siena; of another that fell at Wold Cottage, in Yorkshire, weighing 56 pounds; and a fragment of one that was seen falling in the East-Indies.

\section{VOLCANIC PRODUCTIONS.}

A collection of volcanic products, from Mounts Vesuvius, Somma, and Atna; vesicular, slag. CASES $1 \& 2$. gy, glassy lavas, tuffas, with several other volcanic ejections; leucites: Vesuvians in a calcareomicaceous substance, \&c.-Pseudovolcanic rocks. Lavas and other volcanic productions, in lajoge polished pieces.

CASP 3. MISCELLANEOUS LARCE SPECIMENS OF MINERALS.

(Shelves 1-3.) Various minerals, mostly of the limestone genus; shell marbles; several moC. 6 S difications of crystallized carbonate of lime.

(Shelf 4.) Limestone and manl slate, with dencritical Ggures. Florentine marble. 
ROOM VIII.

(Shelf 5.) Fibrous limestone, Flos ferri: Nat. Hrst. stalactites from the grotto of Antiparos; calcareous incrustation on stalks, \&c; large rhomboidal fragment of double refracting spar, \&c.

(Shelf 6.) Foliated and fibrous gypsum; selenite ; fluor spar, \&c.

CASE

5.

(Shelves 1-3.) Large groupes of rock crystal; quartz druses; nodules of calcedony, \&c.

(Shelf 4.) Hollow nodules of flint, coated ith quartz crystals; a rounded pebble containing water; pudding stones; porphyry ; serpentine, \&c.

(Shelf 5.) Large agate balls; large pieces of rock crystal including substances, such as chlorite, rutile, \&c.

CASES

(Shelf 6.). Compact and lamellar barytes $6-9$. (cauk), \&;c.; mica (Russian glass).

Empty.

CASE

A collection of Derbyshire minerals, formed by 10. Mr. White Watson, partly arranged according to the succession of strata in which they are found.

(Shelf 1.) Peat; argillaceous grit; clays.

(Shelf 2.) Argillaceous ironstones, and ferruginous clays, with and whout petrifactions.

(Shelf 3.) Nodules of argillaceous ironstone: septaria; several varieties of coal. 


\section{3}

(Shelf 4.) Varieties of sandstone; breccias; ronh vin. granite; shales; rotten stône, \&c.

(Shelves 5.6.) Several varieties of limestone, most of them with petrifactions, such as entrochi, cockles, \&c.; sevcral varieties of hornstone, or chert.

(Shelf 1.) Various vein materials : combinakions of galena, limestone, barytes, blende, fluor spar, \&c.; breccias of limestone, hornstone, \&c.

(Shelf 2.) Vein materials; rarious limestones with rake and flat veins composed of gylena, blende, fluor spar, barytes, \&c.; slickensides of galena and of fluor.

(Shelf 3.) Pitumens of various consistence, separate and on limestone, on fluor spar, \&c.; elastic bitumens of several degrees of softnesś.

(Shelf 4.) Marbles of various colours, with their natural fracture, and polished: white and variegated alabaster: efflorescent and other varieties of selenite on limestone, \&c. ; white and coloured clays and porcelain earths.

(Shelf 5.) Several varieties of compact limestone : shell and coralline marbles, polished and unpolished; porous limestone with siliceous shells, called bur, used for hand-mills: tophus, \&c.

(Shelf 6.) Hornstone, or chert of various kind's, separate and combined with limestone.

(Shelf 1.) A collection of stalactites and

CASE 11. 


\section{4}

RooM VII, watricles formed in limestone caverns, some cut NAT.ïsт. and polished; calcareous incrustations, \&c.

(Shelves 2-3.) Calcareous spar in various forms of crystallization.

(Shelf 4.) Several varieties of amethystine fiuor spar; most of the pieces cut and polished.

(Shelf 5.) Topazine and other varieties of finor spar, with barytes, blende, iron pyrites, \&c., mostly cut and polished.

(Shelf 6.) Blue and other fluor crystals of the cubic form, with calcareous spar, blende, barytes, gralena, \&c.; polished squảre pieces of topazine and other fucr spar.

CASE

(Shelves 1.2.) Several varieties of amygdaloid, toadstone; nodules of quartz, calcareous spar, \&c. mountain cork, bitumen, \&c. in toadstone; several pieces of amygdaloid cut square and polished; bluish and other clays, found between the limestone and toadstone strata.

(Shelf 3.) Several varieties of black and brown blende on fiuor spar, \&c. ; calamine, massive, celJular, \&z., in combination with blende, galena, \&c.

(Shelf 4.) Galena, common and compact: peacock galena, slickensides, \&c. white and green lead ores, massive and crystallized, accompanied with galena, brown ironstone, \&c. ; cop: per pyrites of various colours on calcareous spar, 


\section{5}

baryes, \&c.; iron pyrites on fluor spar, galena, Room vmr. \&c. ; friable black manganese ore (black wad). Nat. Hast:

(Shelf 5.) Barytes, compact and lamellar, several varieties cut and polished; a ball of lamellar barytes, with a cavity filled with native sulphur : columnar barytes, \&c.

(Shelf 6.) Varieties of earthy barytes ; amethystine and other fluor spar crystallized in cubes, with iron pyrites, galena, \&c.; small detached quartz crystals, with the reddish earth in which they are found, \&c.

(Shelf 1.) Fossil wood, shells, \&c.

(Shelf 2). Varieties of common quartz, and rock crystals: large brown crystals, called smoky topazes.

(Shelf 3.) Amethyst druses; calcedony jaspers; hornstones, cut and polished, rose. coloured hornstone containing manganese; Constantine flint, \&c.

(Shelves 4-5.) Several variegated jaspers; ribbond-jaspers ; jasp-agates; woodstone ; feldspar: green feldspar, called amazone stone.

(Shelf 6.) Calcareous spar; coloured compact limestones: Constantine marble; selenite. 
moom vir. (Shelves 1-2.) Fossil wood; brown mica; Nwr. Hist. chlorite; actinote; asbestus ; noble serpentine, CASE \&Ce.

15. (Shelf 3.) Some varieties of green porphyry. (Shelf 4.) Iron and copper pyrites; brown ironstone, \&c. Native copper, massive and crystallized.

(Shelf 5.) Several varieties of fibrous and compact malachite; earthy copper azure, \&c.

(Shelf 6.) Crystallized foliated red copperore; compact vitreous copper. Native gold; de composed auriferous pyrites. Silver ores; hornsilver, red lead ore, \&c.

CASE Mountain rocks and other minerals, from 16. the South Sea: King George's Sound, New Georgia, \&c.

(Under Table 1.) A large slab of Labrador spar: various volcanic productions; a large piece of galena drused with quartz crystals; a mass of native and red copper from Cornwall; elastic bitumens from Derbyshire, \&c.

(Under Table 2.) A table, representing some of the strata in Derbyshire, by Mr. White Watson; volcanic productions; a large mass of Obsidian, called also volcanic glass, from Iceland; joint 
joints of the Basaltic columns forming the Giants' Causeway; \&c.

(At the Fire-place.) Two obelisks made of a red compact limestone from the Island Tiree, one of the Hebrides: a calcareous hollow incrustation taken ont of a square waterpipe.

(In the Window to the left.) Large rock crystals from Madagascar, one of them including a considerable quantity of chlorite.

(Within the Saloon Door.) Two frames containing a collection of calcedonies and carnelians with arborescent and other figures, called Mocha stones.

\section{NINTH ROOM.}

In this room aredeposited the Petrifactions and Shells.

Petrified corals, madrepores, echini, \&c.

Petrifactions and casts of cornua Ammonis, the species of which are unknown in a recent state.

Various petrifed univalves, in clusters.

Ditto, bivalves.

Various fossil remains of the animal kingdom.

Ditto: among these is a large fossil jaw, from

ROOM 1X.

CASES

$1 \& 2$

3.

4.

$5 \& 6$.

7.

8.

Maestricht in the Netherlands, which by some naturalists has been supposed to belong to an unknown species of crocodile; and by others to some animal of the whale tribe.

Fragments 


\section{8}

RODM 1X.

Framents of fossil bones, among which is Nat. His.T. an under jaw of the North American animal

9. called the Mammoth. Several teeth of the same animal are preserved separate; and one has be $\_n$ cut across to show the thickness of the enamel.

10. Many species of fossil elephants' grinders, and some also of the Mammoth.

11. Various fossil bones, tusks, \&c.

12. Ditto; and fossil horns. On the shelves 4 and 5 are fragments of fossil bones from the Rock of Gibraltar.

13 \& 14. Fossil remains and impressions of "vegetables.

15.

A human skuil and a Roman sword incrusted, found in the Tiber.

16. Engraved nautili and other shells; and different marine productions.

\section{CRACHERODEAN COLIECTIONOF SHELLS.}

In this table is deposited Mr. Cracherode's

TABLE valuable collection of shells. Among these some of the most remarkable are the following:

\section{Univalves.}

(Division 1.) A paper nautilus or argonaut shell, remarkable for the slightness of its fabric, and the elegance of its shape. It is inhabited by an animal not unlike a cuttle fish, which, by extending: 
extending a pair of membranes adhering to the top of its longest arms, has the power of sailing on the surface of the sea.*

Agate and zebra snails: one of these being ROOM IX.

Nat. Hist. TABLE polished appears of a beautiful rose colour.

(Div. 2.) Cone shells; a very rich assortment : among these are tile admirals : the most remarkable of which are the orange admiral, and the Cedo nulli : porcelain shells or cowries; the argus cowry, and the orange cowry; the latter from New Holland; sea ears, which are usually of an obscure colour externally, but of a bright pearl-colour internally; when uncoated and polished the outside appears highly brilliant.

(Div.3.) Snails properly so called, of various kinds; one of the most remarkable is the ringent or grinning snail, having the opening divided by tooth-like processes.

Murices; among which is the Murex tribulus or thorny-woodcock shell: several trochi, nerites, \&c.

(Div. 4.) The carrier trochus, covered with fragments of stone; the wentle-trap; mitres; a music shell; the grcat oriental volute, or Voluta $\mathrm{K}$ magnifica ;

* For an ample, as well as accurate, description of this curious animal, consult the third volume of the Mollusco, in Sonnini's ein targed edition of the Wurls of Buftion. 


\section{0}

room Ix. magnifica; the imperial volute; the orange flog Nar. Hist. volute, \&c.

TABLE

1.

\section{Bivalves.}

(Div. 5.) The Chinese heart-cockle; the yellow heart-cockle; the red anomia, \&c.

(Div.6.) The mother-oi-pearl shell; in it young or small state; the hound's-ear oyster; the cock's-comb oyster; many beautiful shells of the scallop kind.

(Div. 7.) Several varieties of the red and white thorny oysters; tellinæ, \& c'. .

\section{Multivalves:}

Among the most remarkable of these are the barnacle shells, some of which 'often adhere to the bottoms of ships and to other substances one of the most elegant species occurs in this collection, forming a group of numerous individuals intermised with small muscles, and is called the horn of plenty barnacle, or Lepus cornucopiz.

(Div. 8.) Various beautiful specimens of corals, echini, \&c.; a pink pearl; a Medusa' head, and other star-fish, \&c.

It is here to be observed, that the more generat and scientifc, but less splendia collection of shells "belonging to the Museum, is deposited in drawers in the imposts round the room. 
This table contains a great variety of foșsil crabs, fishes, and other marine animals, among the rest some curious encrinites.

Beneath this table are some large specimens of Mammoth and elephant's tusks, and of cornua Ammonis.

In this table is deposited a conșiderable collection of fossil shells, echini, \&c. none of which, however curious, are likely to attract the notice of those who are not versed in natural history.

Several fine specimens of full sized mother-ofpearl shells, and of the pinna marina, with the natural tuft of silk by which the inhabitant fastens itself to the rocks, \&c. with some gloves made of it : some groupes of barnacles on pieces of wood.

Shells of yarious kinds, too large to be inserted in the collection : sea worms, some adhering to glass bottles:

On the tops of the cases round this room are placed several very large shells, among which, the most remarkable is the great clamp shell or Chama Gigas, the largest of all known shells? and a native of the Indian seas.

Along the bottom of the tables in this and the next room are deposited a great number of volumes and packets, containing collections of tried planks.

ROOM R.

NAT. Hist.

TABLE

2.

TAPLE 3.

TABLE 4.

TAB LE

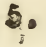




\section{TENTH ROOM.}

VEGETABLES.

ROOM Xr. In the Cases 1 to 6, and part of Case 24, are Nito Hist.

deposited numerous specimens of vegetable productions : the following are the most remarkable :

CASE Various seeds and seed vessels, particularly 1. that of the Nelumbo; the root of an Asiatic fern, popularly called the vegetable lamb, from the rude resemblance it bears to a lamb, when placed in an inverted position, as in the present specimen; cones of firs, \&c.

2 Various specimens of lagetto bark, \&c.

Various gourds. On the bottom shelf, the double or divided cocoa-nut, a rare fruit belonging to the palm called Lodoicea Maldivica, growing on the coasts of the Indian island Praslin.

4. Various cocoa-nuts; a cactus melocactus; a top of a cabbage tree.

3. Various specimens of wcods; roots; worm. caten wood.

6. Morbid excrescences on trees, \&c.

23. Fruits of various kinds in spirits.

In the corner of the room between cases 6 and 7 , is a fine specimen, in spirits, of the fructification of a palm tree. 


\section{3}

ZOCPHYTES.

A numerous collection of madrepores, millepores, \&c. In Case 8, on shelf 5 , is a curious specimen of the lettuce madrepore.

In four frames over the chimney-piece are preROOM X. NaT. Hist. CASES $7 \& 8$. served a great many specimens of British corallines: they are deposited in such a manner as to represent landscapes, and consist of the several species, figured and described by the celebrated Mr. Ellis, in order to prove them a tribe of marine animals of the polype division, and not vegetables, as formerly supposed.

Several spccimens of red coral; jointed black and white Isis coral : some species of alcyonium. Sea fans.

9.

A great variety of gorgonia, or hornȳ corals. Sponges. A numerous and miscellaneous collection of $20 \& 21$. insects preserved in spirits: among which are many scorpions, centipedes, and spiders; some very large: a lanthorn fly; locusts, \&c. also a considerable number of caterpillars, and aureliz: several crustaceous animals, \&c.

A great variety of animals of the Mollusca $22 \& 23$. tribe; some well preserved specimens of the cuttle fish; various inhabitants of shells; tape worms, and guinea worms; several zoophytes; a fine

11 to 16.

17 to 19 . 
foom x. specimen of the Pennatula argentea, or silyes Q5. Hssr. sea-pen, from the East-Indies; the red or common sca-pen, the grey ditto, \&x.

In the Table 1 and 2 is deposited Sir Hans \$loane's collection of insects. Considering the length of time since this collection was formed, and the perishable nature of articles of this kind, it will not appear extraordinary that this part of the Museum should be inferior to the rest in point of preservation.

FABZZ Among these insects will be found the great 1. Hercules bectle; the elephant beetle; different species of golden beetles; the insect known by: the name of walking leaf; the great lanthorn $\mathrm{fly}$; locusts of various kinds; butterties; moths diragon flies; bees; wasps, \&c.

In the Divisions 1 to 4 are the apterous in sects: scorpions; spiders, among which is the tarantula; scolopendræ or centipedes; juli or galley-worms: also a very numerous collection of çhrysalides or aurelix; various nests of wasps, \&.c.

In the division 4 to 8 are the crustaceous animals; the West-Indian land-crab; lobsters; various spider-crabs; soldier-crabs ; the Monoculus Polyphemus, usually called the king of horse-shoe crab.

A large series of the insect tribe, among which 
are the more select specimens, is, in order to prewent their receiving further injury by constant exposure to light, deposited in a large cabinet zuserted in Case 24 , and in four smaller ones zinder the Tables 1 and 3 . In i small separate. Case is contained a specimen of that curious and brilliant insect, the Curculio imperialis, commonity sermed the diamond-beetle.

This table contains a great variety of asteriz or star fish; Medusa's heads; echini or sea urchins; TABLE and lastly, several models in wax of cuttle fish; Medusa, and' vermes.

Against the end of Table 2, farthest from the fire, is a small cabinet containing several miscellaneous articles of natural history, from Jamaicas, collected and presented by Samuel Feiton, Esq. : and on the top of this cabinet is placed a fine specimen of a large lând-crab (Cancer latro) from Amboyna.

In the imposis round this room runs a series of drawers, containing a very numerous collection of seeds, fruits, and other vegetable articles.

Over the Cases 1 to 6 are placed some paln leaves, \&c.; the large one in the centre belonging to one of the umbrella or fan-leaved palms: also paintings of the cactus grandifforus or great ereeping cereus, and of the cochineal cactus. 
ROOM X. NAT. Hist. neal plantation.

Over the chimney are two fern trees.

Over the door next the chimney is a small or young (but very perfect) specimen, of a curious fish allied in its general appearance to the swordfish, but which by some has been considered as belonging to the tunny tribe. It grows to a vast size, and is sometimes known to attack a ship (which it perhaps mistakes for a whale), and that with such force as to drive the horn or sword through the timber. An example of this, from a larger fish of that kind, is preserved in the same frame: and also the tail of a large one over the Case.

\section{ELIVENTII ROOM.}

ROOM XI.

The birds in this room are disposed, so far tis convenience would admit, according to the Linnæan mode of arrangement, wiz. into six great divisions or orders, the separations of which are marked by white lines between each. Some bírdis however, on account of the large size of the cases in wich they are contained, conld not conveniently be stationed in their proper orders and are therefore disposed on the upper pait of the general divisions. 
The first Linnæan order consists of the AccIPITRES, or predaceous birds; and contains the Nat. Hist, vultures, eagles, hawks, owls, and shrikes. In this order the most remarkable birds are, the Californian vulture; the sharp tailed eagle fron New Holland; the great snowy owl; the fuliginous owl; the great shrike; and the Barbary shrike.

The next order contains the $\mathrm{P}_{\mathrm{IC}}$, or pies; and consists of various tribes, greatly differing in size and general appearance, viz. the maccaws and parrots; the crows, and jays; the rollers; the woodpeckers; hornbills; cuckows; bee-eaters; king-fishers; toucans; creepers; hummingbirds, \&c. In this tribe the most remarkable birds are the great scarlet maccaw; the blue and yellow ditto; the noupareil parrakeet from New Holland; the yellow breasted toucan; the helmet hornbill; the Indian roller; and various kinds of humming-birds, among others that rare species the harlequin humming-bird, distinguished by the great variety of its colours; and lastly, the least humming-bird, the smallest of all the feathered race.

The next or third Linnæan order consists of the Anseres or web-footed birds, such as the swan and goose tribe; the gulls; the penguins: and many others. In this tribe the most remark- 
RooM Xr. able are, the black swan, from New Holland: NAT. Hist. the lobated duck from ditto : the short-billed, or half-webbed goose; the great penguin; and different species of pelicans.

The fourth Linnæan order contains the GraLL E or waders, and consists of the heron and bittern tribes; the spoonbill; the screamer; the curlews, and ibises; the plovers; and many others. In this order the most remarkable specimens are, a young hargil, or giant crane, from India, which, when full-grown, is by far the largest of all the heron tribe; the tiger-bittern, an elegant South American species; the horned screamer from South America; the rose coloured spoonbill, and the scarlet ibis, both from South America.

The fifth Linnæan order consists of the $\mathrm{G}_{\mathrm{AL}}$ LINE, comprehending such birds as are more of less allied to the common fowl. It consequently contains the pheasant and partridge tribe, the curasso, \&c. In this division the principal specimens are the argus pheasant, from Sumatra; the black or crested Curasso bird; the great woodgrous or urogallus; and the crested Californian quail.

The sixth and last Linnæan order of birds contains the PASSERES; and consists of a great variety of different genera, from the pigeons to the swallows and the goat-suckers. In this order the most remarkable 
remarkable specimens are, the great crowned Indian pigeon; the shining African thrush; the $\mathrm{NAT}_{\mathrm{T}} \mathrm{H}$. scarlet or Virginian grosbeak; the long shafted goat-sucker from Sierra Leona; and the European goat-sucker.

It has before been observed, that some birds, on account of their inconvenient size, could not be admitted into the general assortment. Of these the most remarkable is the cassowary, an Indian bird, which some ornithologists place among the Grallæ, others among the Gallinæ, and others in a particular division distinct from both.

We must not omit a cyprious picture, executed long ago in Holland, of that extremely rare and curious bird the Dodo, belonging to the tribe Gallinæ, and a native of the island of Bourbon.

The picture was taken from a living specimen, brought into Holland soon after the discovery of the passage to the East-Indies by the Cape of Good Hope, by the Portuguese. It was once the property of Sir Hans Sloane, and afterwards of the celebrated ornithologist George Edwards, who presented it to the British Museum.

In this table are preserved the nests of various birds, amongst the most curious of which are seTABLE veral hanging-nests, chiefly formed by birds of the oriole tribe; nests of a small species of Asiatic swallow, resembling isinglass in substance, 
rooM XI. and considered as a great delicacy by the Chinese, NAT.Hist. who use it in preparing a rich soup called birdnest soup; two nests of a small bird called the taylor-bird, composed of leaves sewed together ; bills of various rare birds, of which the most remarkable are several kinds of rhinoceros bird's bills; quills ; feathers of the great South American vulture called the Condor; a leg of the Dodo, in a glass.

TABIE In this table are deposited a variety of eggs and II. nests: among the former may be noticed the eggs of the ostrich, the cassowary, \&c.

In this room are preserved several of the rarev quadrupeds. Among these the most curious are the following:

\section{In the Cases between the Windows.}

The black ourang outang, in a young state; the chesnut ourang outang, in a young state; the long-tailed macauco; the shunk; the ermine, \&.c.

\section{In other Parts of the Room.}

The sea otier; the musk, from Thibet; the great armadillo; the long-tailed Brasilian porcupine; the Canada porcupine, remarkable for its thick form, the length of its hair, and the shortness of its spines; the lemurine opossum from New Holland; the vampyre, or great South Ameŗican 
rican bat; the Platypus anatinus or cluckbill (by roos xrr. some called Ornithorynchus paradoxus), from NAт. Hist, New Holland, the most singular of all quadrupeds; a large antelope ; a small ditto ; the longtailed manis or pangolin; the short tailed ditto; sloths, in a very young state, one the two toed, the other the three-toed species; an elegant specimen of the two-toed ant-eater.

\section{TWELFTH ROOM.}

This room contains a general and extensive room $x i r$; collection of fishes, serpents, tortoises, lizards, frogs, \&c. as well as many specimens of quadrupeds, preserved in spirits.

Among the most curious of the fishes, are the torpedo; the electric gymnote, popularly called the electric eel; the remora; the flying-fish, \&c.

Among the quadrupeds the most remarkable pre, a very fine specimen of the three-toed sloth; the two-toed ditto; the slender-limbed macauca; the least ant-eater ; and the silky monkey.

Among the tortoises the most remarkable are, the testudo ferox or fierce tortoise, and the testu. do radiata, or radiated tortoise.

Among the frog tribe may be particularized, the Argus frog or North American spotted bullfrog; the pipa or Surinam toad, remarkable for producing 
ROOM XII. producing its young from numerous cells on its Nar. Hig̣t. back; the blue and yellow frog; the large tadpole of the frog called the paradoxical frog, a native of Surinam.

Among the lizard tribe may be observed, the salamander; the chamæleon; the guana; the embroidered lizard, from New Holland; several young crocodiles of different sizes and kinds; and in one bottle the egg of a crocodile, with a young one of a few days' growth. The siren, from South Carclina, resembling in shape and colour, a large eel, furnished with two short legs, situated near the head, and three pair of branched gills on each side of the neck ; the Austrian siren, an extremely rare animal, an inhabitant of the lake Cirenitz or Zitticher Sea, in the duchy of Carniolia ; it is about thirteen inches in length, and of a very pale or whitish rose colour, with four legs, very distant from each other.

Among the serpents, the most remarkable are the following, viz. rattie-snakes of different species, from North and South America; the cobra de Cappello, or spectacle snake, from the EastIndies; the horn-nosed snake, from the interior of Africa; the cerastes or horned viper, from Arrica; the sea-green boa, with white bars on the back, from South America; the boa constricfor, or great boa, from South America, a small 
or young specimen, the animal often growing to ROCM Xit. the length of twenty, thirty, or even more feet. NAT. HIST.

In the glass case in the middle of this room, are contained many specinens of dried fishes; \&c. The most remarkable are the foliated pipefish, from New Holland; and the Southern trachichthys : also a chamæleon dried.

\section{DEPARTMENT OF ANTIQUITIES. \\ FIRST ROOM.}

\section{TERRA COTTAE.}

All the articles in the following Catalogue of Antiquities, unless where it is oiherwise specified, belonged to the collection of the late Charles Towneley, Esq.

Over the door, which fronts the entrance into ROOM 1. this room, is a bust of Charles Towneley Esq., to whose profound knowledge of ancient Sculpture, and zeal in the acquisition of the finest specimens of it, the ration is indebted for the formation of nearly the whole of the splendid collection of Terra Cottas and Marbles contained in this gallery. The bust was presented by his Uncle, John Towneley Esq. It is executed in marble, by Mr. Nollekens.

No. 1. A female statue, probably of one of the Muses.

No. 2. An amphora.

No. 3. A terminalhead of the bearded Pacchus. 


\section{4}

ROOM I.

No. 4. A bas-relief; representing a combat. Ansizurisas: between two Amazons and two Griffins.

No. 5: Ditto, representing the head of a Triton, on each side of which is a cupid riding; on a dolphin.

No. 6. Ditto, representing a group of $\mathrm{Si}-$ lenus and Cupid, before whom is a female Bacchante, dancing and playing on the tambourin.

No. 7. Ditto, representing an engagement between one of the Arimaspi and a Griffin ; on the left of the combatants $i$ the bust of an athletic figure, armed with a battle-axe.

No. 8. Ditto, intencled by the artist as a companion to $\mathrm{No} .7$, and to be joined to it in the manner in which it is here seen. The subject in both picees is precisely the same: the bust, however, in this piece is placed on the right of the combatants, and is armed with a sword and shield.

No. 9. Repetition of No. 6.

No. 10. A bas-relief, representing a hcad of Medusa, on each side of which is an eagle, in the act of seizing, with its talons, one of the snakes which are entwined in the locks of her hair.

No. 11. Ditto, representing a coiple of chimæras lapping water out of vessels, held to them by two youths, who are attired in Phrygian dresses, and are each kneeling on one knee.

No. 12: Ditto, representing a female, who seems to be overwhelmed with affiction. She is 


\section{5}

seated, and is resting her head upon her right ROOM I. arm. while her domestics, from the concern ANTiguitis. which is visible in their countenances, appear to participate in her sorrow. This bas-relief, probably, represents Penelope dejected at the departure of Ulysses.

No.13. A ba-relief, imperfect, representing a fragment of the Medusa's head, on one side of which is a figure of Minerva.

No. 14. Ditto, representing the bearded Bacchus, and a female attendant on Bacchus each if them holding a thyrsus. From the collection of Sir Hans Sloane.

No. 15. Ditto, imperfect, representing a head of Minerva, and a head of Jupiter.

No. 16. Ditto, representing Mincrva assisting the Argonauts to build the famous ship Argo.

No. 17. Ditto, imperfect, representing Venus on the ocean, riding upon a sea horse.

No. 18. Ditto, representing Victory pouring out a libation to Apollo Musagetes. From the collection of Sir Hans Sloane.

No.19. Ditto, representing a candelabrum, lighted for a sacrifice. On each side stands a priestess, who, with one hand, supports the sacred fillets which decorate the candelabrum, and, with the other hand, raises a small portion of her robe, like the figure of Hope on coins of the Roman Emperors. 
поом I. No. 20. A bas-relief, representing Machaon, AnTrevimes. after he has been wounded. He is sitting in the tent of Nestor, who is administering a potion to him, as described in the XIth book of the Iliad. The females, who are in attendance, are slaves. No. 21. Ditto, representing Bacchus and a Faun; the former holds a thyrsus in his left hand, the latter carries a torch in his right hand, and an amphora on his left shoulder.

No. 22. Dito, representing two Fauns kneeling, one of them playing upon the tambourin, the other accompanying him with small musical instruments called crotala. Between them is Ampelus, the lower part of whose figure terminates in branches of the vine.

No.23. Ditto, representing two of the Seasons, Spring and Summer.

No. 24. Ditto, representing Victory sacrificing a bull before a lighted candelabrum, which is used as an altar.

No. 25. Ditto, imperfect, representing Perseus cutting off the head of Medusa.

No. 26. Ditto, representing Victory sacrificing a bull before a small altar, which is placed upon a tripod table.

No. $2 \%$. Ditto, imperfect, representing a female Bacchante offering a basket of figs to the goddess 
goddess Pudicitia. From the collecition of Sir RONM 1.

\section{Hans Sloane.}

No. 28. A bas relief, representing two Fauns gathering grapes into baskets.

No. 29. Repetition of No. 21.

No. 30. A bas-relief, representing Bacchus leaning on the shoulders of a Faun. At his feet is a panther holding up his mouth to receive the wine which is poured from the vase held in the right hand of Bacchus. Before this group is a female attendant on Bachus holding a thyrsus in her hand.

No. 31. Ditto, representing two Fauns, leaning over a large open vessel of wine, as if observing the reflection of their faces on the surface of the liquor:

No. 32. Ditto, imperfect, representing a trophy, before which stands a captive, attended by a guard, and secured by a chain fastened round his right wrist.

No. 33. Ditto, representing two Fauns gathering grapes into baskets. From the collection of Sir Hans Sloane.

No. 34. Ditto, representing Paris carrying off Helen, in a car drawn by four horses.

No. 35. Ditto, representing Egyptian hieroglyphics.

No. 36. Ditto, representing two persons na- 


\section{8}

roov $\mathrm{I}$. vigating the Nile in a boat. In the fore-ground ANтruires. is an hippopotanus, two crocodiles, some birds, $\therefore$ and several plants of the lotus. In the distance are buildings, on the roofs of which are seen three Ibises. The whole of this scenery is viewed through two arches, supported by columus

No.37 A bas-relief, imperfect, representing a vase with two handles, on one side of which is a fanther leaping up, a thyrsus, and the letter A.

No 38. A statue of the Muse Urania.-Both the hands are wanting; but, from the position of the arms, it is probable that the figure held a radius in the right hand, and a celestial globe in the left hand. It is 3 feet ten inches high, and is one of the largest statues which have been found of terracotta.

No. 39. An Amphora. From the collection of Sir IIans Sloane.

No. 40. A statue of a Muse, resting her left arm upon a pile of writing tablets, which are placed upon a square column. The right arm is raised towards the neck. The figure, in its present state, is three feet four inches high; the head is lost.

No 41. An Amphora. From the collection of Sir Hans Sloane.

No. 42. A bas relief representing a short naked human figure, with a beard; be holds, in cach hand, the siem of a plant. On 
each side of this figure is seated a quadruped, noom $\mathbf{r}$. whose head is that of an elderly man, and whose Antravirses. tail terminates in a flower.

No. 43. A bas-relief, representing Cupids supporting festoons of fruit.

No. 44. Ditto, representing a Faun and a Bacchante dancing, and holding between them the infant Bacchus in a basket used for winnowing corn.

No. 45. Ditto, representing the hear of Pan, on each side of which is the head of a Satyr: one of the Satyrs is crowned with branches of pine, and the other with branches of ivy.

No. 46. Repetition of No. 45.

No. 47. A bas-relief, representing the Indian Bacchus received as a guest by Icarus.

No. 48. Ditto, representing two Tauns riding on panthers. The hinder parts of the panthers terminate in vine leaves. Between the panthers is a vase with two handles.

No. 49. Ditto, representing a bull and a lion running in contrary directions. The hind legs of both animals are enveloped in foliage.

No. 50. Ditto, representing a lighted candelabrum, which is composed entirely of a plant. The fames issue from the flower, which grow upon a long stem. On each side stands a priestess, with one hand holding up a small portion of 
ROOM I. her robe (see Nos. 19 and 54), and with the other AxтrQuiries. hand holding one of the branches of the plant.

No. 51. A bas-relief, representing two of the Seasons, Autumn and Winter.

No. 52. Ditto, imperfect, representing the Goddess Salus feeding a serpent out of a patera. The serpent is twined round the trunk of a tree, from a branch of which are suspended two castoff skins of the serpent.

No. 53. Ditto, representing a warrior consulting the oracle of A pollo.

No. 54. Ditto, representing a lighted candelabrum, on each side of which stands a priestess, carrying a patera on her head, and holding up a small portion of her robe with one hand. (See Nos. 19 and 50.)

No. 55. Ditto, representing Theseus slaying

a Centaur.

No. 56. Repetition of No. 18.

No. 57. Repetition of No. 23.

No. 53. Repetition of No. 50 .

No. 59. A bas-relief, representing two Fauns treading out the juice of grapes in a vine-press. On one side is a Faun playing upon the double pipe ; and on the other side another Faun, somewhat aged in his appearance, loaded with a heavy basket of grapes. 
No. 60. A bas-relief, representing a chariot ROOM I. race

No. 61. A repetition of No 6.

No. 62. A bas-relief, representing a mask of Bacchus, between those of a young and an old Faun.

No 63. Repetition of No 62.

No. 64. Repetition of No. 6.

No. 65. A bas-relief, representing two captives in a car drawn by two hor es. The captives have chains fasteried round their necks, and round their ankles, and the ends of the chains are held by persons walking on each side of the car.

No 66 Ditto, representing a bead of Jupiter Ammon, which rests on a flower. The ends of the fillets, with which the head of Jupiter is crowned, are held on each side by a Faun; who is furnished with wings, and whose figure terminates below in foliage, which curls in such a manner as to give the figure the appearance of a Triton.

No. 67. Ditto, representing two Fauns gathering grapes into baskets.

No. 68. Ditto, representing a figure of Victory standing upon a plant, and supporting the branches of it with her hands.

No. 69. Repetition of No. 33.

No. 70. A bas relief, representing Victory sacrificing a bull before a tripod altar. 
BOOM I. No. 71. A bas relief imperfect, representing enrigunins. Theseus riding at full speed, and cutting of the head of an Amazon, whom he has caught by the hair of her head.

No. 72. Ditto, representing Venus carred though the air upon a swan.

No 73. Dito, representing Cupid pressing Psyche, in the form of a butterfy, to his breast.

No. 74. Ditto, representing Cupid llying, with a palm branch in one hand, and a wreath in the other.

No. 7o. A terminal head of the bearded Bacchus.

No. 76 . A female statue, probably of Thalia, the pastoral muse.

No 77. An Amphora. From the collection of Sir IIrans Sioane.

No.78. A female statue, the character unknown. The head and lower arms are modern.

No. 79. A statue of Juno, crowned with an indented diadem. Part of the arms is wanting.

\section{SECOND ROOM.}

GREEK AND ROMAN SCULPTURES。

Room Ir. No. 1. A colossal head of Minerva.

No. 2. A funeral urn, ornamented with equestrian and pedestrian combatants.

No. 3. 
No.3. One of the feet, or supports, of an RoOM Ir. ancient tripod table.

No. 4. A statue of a canephora, anciently made use of as a column. It was one of the caryatides, which supported the portico of a small temple dedicated to Bacchus.

No. 5. A candelabrum.

No. 6. The triangular base of a candelabrum, on the sides of which three genii hold each a part of the armour of Mars, namely, his hel met, his shield, and his sword.

No. 7. A vase, three feet high, with upright massive handles, of an oval form, and ornament= ed all round with Bacchanalian tigures.

No. 8. A statue of Venus, naked to the waist, and covered with cirapery from thence downwards. It was found in the maritime baths of Claudius at Ostia.

No. 9. A vase, two feet eight inches high, of an oval form, with two upright double handles, which spring from the necks of swans. The body of the vase in front is enriched with a group of Bacchanalians.

No. 10. A fountain, ornamented with ivy and olive branches. The water was conveyed through a perforation on the back part of this monument to a serpent's head, in which a learten 
ROOM II. pipe was introduced, part of which still remains Axtrevities. in the mouth.

No. 11. A colossal head of Hercules, dug up at the foot of Mount Vesuvius, where it had been buried by the lava of that volcano. From the collection of Sir William Hamilton.

No. 12. A colossal head of Hercules in a very ancient style of Greek sculpture.

No.13. A fragment of one of the three supports of a tripod basin, composed of the head and ncck of a lion. On the forehead are the horns of a goat.

No. 14. The capital or upper division of a votive cippus.

No. 15. A part of one of the supports of an ancient table, ornamented with a figure of Victory, elaborately hollowed out between the two volutes. This fragment is inserted in a modern pedestal.

No. 16. A colossal head of Minerva, a specimen of very earky Greek work.

No. 17. A statue of Cupid bending his bow. Purchased at the Sale of the late Rt. Hon. Ed= mund Burke.

\section{THIRD ROOM.}

GREEK AND ROMAN SCULPTURES.

Rоoэм III. No. 1. A bas-relief, representing an old Faun struggling with a nymph.

No.2. 


\section{5}

No. 2. A bas-relief, representing a candela- room IIr. brum.

No.3. Ditto, in the centre of which is a pilaster-pedestal, supporting a vase, the handles of which are composed of Griffins' heads. Several other mythological symbols are represented on this monument.

No. 4. Ditto, representing Bacchus received as a guest by Icarus.

No. 5. Ditto, which appears to have been a funeral monument to a father and his two sons, who are in Roman dresses. The other figures on this marble are Divinities. The inscription, which was in Greek, is very nearly obliterated.

No. 6. Ditto, in the flat early style of Grecian sculpture. It represents Castor managing a horse.

No.7. Ditto, representing Hercules securing the stag, which, at the command of Eurystheus, he had pursued a whole year in the forests of Arcadia.

No. 8. Blank.

No. 9. A bas-relief, divided into three compartments. In the upper division, the infant Jupiter is represented riding on the Amalthean goat; in the middle, a Triton is seizing a bull by the horns; and in the lower, two men are carrying a hog towards an elevated spot of ground to be sacrificed.

No. 10. Ditto, representing a festonn of vine branches, supported by the skulls of bulls. In 


\section{6}

Room Iri. the centre, above the festoon, is a mask of a Antiguities. Faun. It has served as a decoration in the insicie of a circular building.

No. 11. A bas-relief, representing the Dioscuri on horseback. From the collection of Sir William Hamilton.

No 12. Ditto, representing a Bacchanalian group, consisting of three figures; the first, a Bacchaut playing on the tambourin; the second, a Faun playing on the double pipe; and the third, an intoxicated Faun holding a thyrsus.

No. 13. Witto, representing $V$ ictory offering a libation to Apolio Masagetes. From the collection of Sir Fillam Bamiton.

No. 14. Ditto, which has served as an ornament on the outside of a circular building. It consists of a couple of branches, proceeding from one stem, and curling in opposite directions.

No 15. Ditto, representing the Centaur Nes. sus carrying of Deianira.

No. 16. Ditto, representing a cow drinking out of a circular vessel, whilst she suckles her calf.

No. 17. Two terminal heads, joined back to back, one of the bearded Bacchus, the other of Libera.

No. 18. A statue of the Goddess Fortune.

No. 19. A terminal head of the bearded Bac: chus, of very early Greek work.

No. 20 . 
No. 20. A head of Aratus.

No. 21. A head of Mercury. Purchased at Antiguities. the Sale of William Chinnery, Esq.

No. 22 A statue of Venus.

No. 23. An unknown head, supposed to be that of a Titan It is highly anirated, and is looking upwards, apparently in great agitation.

No 24. A statue of a Faun.

No. 25. A terminal head of Homer, repres sented in an advanced age, with a sublime and dignified character.

No. 26. A bust of Zeno.

No. $2 \pi$. A terminal head of the bearded Bac. chus.

No. 28. A recumbent figure of Diana, resting on her left hand, and advancing her right hand. Upon the plinth is her bow, the extremities of which are decorated with the heads of Griffins.

No. 29. An entire terminus of the bearded Bacchus, six feet high.

No. 30. A terminal head of the bearded Bacchus.

No. 31. A statue of a youth holding with bith hands a part of an arm, which he is biting. This statue belonged to a group, originally composed of two boys, who had quarrelled at the game of the Talus, as appears by one of 
noom IIr. those bones, called Tali, remaining in the hand of 2smeurres, the figure which is lost.

No. 32. A terminal head of Pericles, helmeted, and inscribed with his name.

No. 33. A statue of a Faun, inscribed with the name of the artist.

No. 34. A terminal head of Epicurus.

No. 35. A terminus of Pan playing upon a pipe.

No. 36. A Greek inscription upon a circular shield, containing the names of the Ephebi of Athens under Alcamenes, when he held the office af Cosmetes.

No. 37. A terminus of an unknown female.

No. 38. A circular votive patera.

No. 39. A bronzé head of Homer. Presented in 1760, by the Earl of Exeter.

No. 40. A circular votive patera, with a head of Pan in very high relief.

No. 41. A Greek sepulchral monument. The bas relief in front represents a trophy, on one side of which stands a warrior, and on the other a female figure feeding a serpent which is twined round the trunk of a tree, on which the trophy is erected. On the right of these figures is the fore part of a horse. An inscription on the top of this monument contains a list of names, pro. 
bably of those who fell in some engagement. room it. Presented by the Rt. Hon. Sir Joseph Banks and the Hon. A.C. Fraser.

No. 42. A terminal head of Periander.

No. 43. A repetition of No. 33.

No. 44. A terminal head, said to be that of Homer.

No. 45. A statue of Actæon attacked by his dogs.

No. 46. A terminal head of the young Hercules. It is crowned with the leaves of the poplar.

\section{FOURTH ROOM.}

GREEK AND ROMAN SCULPTURES.

No. 1. A bust of Trajan with the breast Roos IV. naked.

No. 2. A bronze statue of Hercules, carrying away the apples from the garden of the Hesperides.

No. 3. One of the feet or supports of an ancient tripod-table.

No. 4. A head of Apollo of very early Greek work:

No 5. A statue of Thalia, found at Ostia, in the maritime baths of the Emperor Claudius.

No. 6. A head of Decebalus.

No. 7. A bronze statue of Apollo.

No. 8. One of the feet or supports of an 
room IV. ancient tripod table, executed in porphyry. It Axtreuities. represents the head and leg of a panther.

No 9. A colossal head of Marcus Aurelius, who is represented as the Pontifex Maximus, in his sacrificing robes.

No. 10. A colossal bust of Lucius Verus, covered with the Imperial paludamentum.

No 11. A group of Bacchus and Ampelus.

No 12. A head of the young Hercules.

No. 13. A head of Juno.

No. 14. A statue of Diana.

No 15. A bust of Hadrian, with the breast naked.

\section{FIFTH ROOM.}

ROMAN SEPULCHRAL ANTIQUITIES.

Room v. No. 1. A monumental inscription to Q. Aufidius Generosus. Presented by Thomas Hollis, Esq.

No. 2. Ditto, to Aelia Fortunata, Aelius Telesphorus, and others. Presented by Thomas Hollis, Esq.

No 3. Ditto, to M. Nrvius Proculus. Pre. senied by Thomas Follis, Esq.

No. 4. A sepuichral urn, with an inscription to Vernasia Cycias.

No. 5. Ditto, with an inscription to T. Sex. Agatha, Presented by Thomas Hollis, Esq.

No. 6. 


\section{1}

No. 6. Two earthen ollæ, placed in the man- Room v. ner of those which contained the ashes of the Anrigurries, slaves, and the inferior orders of the Roman people. The monumental inscription, in front of them, records the names of Anniolena Maxima, and Servilia Irene.

No. 7. A sepulchral urn, with an inscription to Pompeius Justinianus.

No. 8. Ditto, with an inscription to T. Titulenus Isauricus.

No. 9. Blank.

No. 10. A sepulchral urn, with an inscription to Fl. Elius Victor.

No. 11. Ditto, with an inscription to Silia Attica.

No. 12. A sepulchral vase, found in a tomb near Naples.

No. 13. A sarcophagus, on the front of which is represented the lamentation of a family over a corpse.

No. 14. A sepulchral urn, with an inscription to Serullia Zosimenes.

No. 35. Ditto, with an inscription to $\mathbf{P}$. Licinius Successus.

No. 16. Blank.

No, 17. A sepulchral urn, with an inscriplion to Cossutia Prima.

Ne, 18. Ditto, with an inscription to Claudia 
ROOM v. Fortunata. From the collection of Sir Hans Axmiguriss. Sloane.

No. 19. Two earthen ollæ, similar to those described at No. 6. The monumental inscription, placed in front of them, records the names of P. Stenius Rufus and Plosurnia Salvilla.

No. 20. A monumental inscription to Eutychia. Presented by Thomas Hollis, Esq.

No. 21. An Etruscan cinerary urn, in baked clay. The bas-relief in front represents the hero Echetles fighting with a ploughshare for the Greeks at the battle of Marathon. Upon the cover is a recumbent female figure.

No. 22. A monumental inscription to $C$. Julius Primigenius. Presented by Thomas Hollis, Esq.

No. 23. Ditto, with an inscription to Lucretia. Presented by Thomas Hollis, Esq.

No. 21. An Etruscan cinerary urn, in baked clay. The story of Echetles is represented in front (see No. 21.), and on the cover is a recumbent female figure. The figures on this monument were originally painted. On the upper part of the urn is an Etruscan inscription in red letters. From the collection of Sir William Hamilton.

No. 25. A monumental inscription to Cappullius Meirobius.

No. 26 . 


\section{3}

No. 26. A sepulchral urn, with an inscrip. Room v. tion to Clodia Romulla. From the collection of Anтiguitus. Sir Hans Sloane.

No. 27. A sepulchral urn, with an inscription to Junia Pieris.

No. 28. An earthen olla, similar to those described at No. 6. The monumental inscription placed in front of it records the name of Opilia Faustilla.

No. 29. A sepulchral urn, with an inscription to Colia Asteris. From the collection of Sir William Hamilton.

No. 30. Ditto, with an inscription to $\mathbf{P}$. Octanius Secundus.

No.31. A fragment of a testamentary inscription, cut from a sepulchral cippus.

No. 32. A sepulchral urn, with an inscription to Pompeius Locusto, Attilia Clodia, and Pompeius. From the collection of Sir William Hamilton.

No. 33. Ditto, with an inscription to C. Magius Pal. Heraclides.

No. 34. An Etruscan cinerary urn, in baked clay. The bas-relicf in front represent the single combat between the two brothers, Eteocles and Polynices. The two female figures, who are standing near the combatants, are Furies. An Etruscan inscription is painted in red letters on 
ROOM V. the upper part of this urn; on the cover is a re: Anтrieurizs. cumbent female figure. From the collection of Sir William Hamilton.

No. 35. A sarcophagus, on the front of which various figures of Cupid and Psyche are represented.

No.36. A sepulchral urn, with an inscription to D. Albiccus Licinus.

No.37. Ditto, with an inscription to Flavia Eunya.

No. 38. A monumental inscription to Dasumia Soteris.

No. 39. A sepulchral urn of alabaster. From the collection of Sir William Hamilton.

No. 40. A sepulchral urn, with an inscription to Isochryses.

No. 41. An earthen olla, similar to those described at No. 6. The monumental inscription placed in front of it, records the name of Apuleia Tychen.

No 42. A monumental inscription to Flavią Provincia.

No. 43. A sepulchral urn, with an inscription to Pilia Philtata. From the collection of Sir William Hamilton.

No. 44. A monumental inscription to Isidorus. Presented by Thomas Hollis, Esq.

No. 45. A mosaic pavement, lately discovered 
In digging the foundation for the new buildings поом $\mathrm{V}$. at the Bank of England. Presented by the Antreurties. Directors of the Bank.

\section{SIXTH ROOM.}

GREEK AND ROMAN SCULPTURES.

No. 1. A medallion, representing in profile Room vi, the bust of an unknown Greek philosopher.

No. 2. Part of the front of a sarcophagus, representing Achilles among the daughters of Lycomedes.

No. 3. A bas-relief, cut from the end of a sarcophagus ; it represents two Fauns punishing a Satyr.

No. 4. Part of the front of a large sarcophagus, representing a marriage.

No. 5. The front of a sarcophagus, representing the nine Muses, with their respective attributes.

No. 6. A bas-relief, cut from the end of the same sarcophagus as No. 3. It represents two Cupids and a Faun carrying an intoxicated Satyr. No. 7. Part of a sarcophagus, representing a carpentum, or funeral car, drawn by four horses.

No. 8. A medallion, representing in profile the bust of an unknown Greek philosopher. It is similar to No, 1, but of a later time and inferior sculpture. 
Room Vi. No. 9. The front of a sarcophagus, repreAnтrquities. senting captive Amazons, with their shields and battle-axes.

No. 10. A fragment of a sarcophagus, representing Bacchus with a thyrsus in his left hand, and with his right arm thrown over the shoulder of a Faun.

No. 11. A fragment of a magnificent sarcophagus, representing an elderly man, with a manuscript roll in his hand, which he is reading. Before him stands a Muse holding a mask.

No. 12. The front of a sarcophagus, representing a Bacchanalian procession.

No. 13. Heads of Paris and Helen, in altorelievo.

No. 14. The front of a sarcophagus, representing Genii, supporting various pieces of armour. On a shield, in the centre, is an inscription to Sallustius Iasius.

No. 15. A head of Jupiter.

No. 16. A terminal statue of a youth, who is represented with the attributes of Mercury.

No. 17. A rotive altar, sacred to A pollo.

No. 18. A head of Apollo Musagetes, resembling, in the disposition of the hair, and in the character of the face, the head of a Muse.

No. 19. A Greek inscription, being a decree of the people of Athens, and of the Piræus, in 
honour of Callidamas. Presented by the Dilet- room vi. tanti Society.

No. 20. A votive statue of Diana triformis, with a dedicatory inscription round the plinth.

No. 21. An altar of Roman work, ornamented with Egyptian figures.

No. 22. A bust inscribed to the memory of $\mathrm{Cl}$. Olympias, by Epithymetus, her freed man. Purchased at the Sale of the late Rt. Hon. Edmund Burke.

No. 23. A funeral monument of Xanthippus, who is represented sitting in a chair, and holding a human foot in his right hand.

No. 24. A statue of a Satyr.

No. 25. An altar on which various Egyptian figures are represented. It is of Roman work.

No. 26. A head of an Amazon, in the early style of Greek sculpture.

No. 27. A Greek sepulchral monument, with a bas-relief, and an inscription to Mousis, who was a native of Miletus, and daughter of Argæus. Presented by Thomas Hollis, Esq.

No. 28. A figure of Victory, sacrificing a bull.

No. 29. A bust of Hadrian, with the Imperial paludamentum.

No. 30. A foot covered with a sandal.

No. 31. A statue of Diana Lucifera, of which the head and arms are lost. It was found 
Room vi. at Woodchester in Gloucestershire. Presented Antiquitiss. by Samuel Lysons, Esq.

No.32. A small statue of Jupiter sitting. $\mathrm{He}$ is represented in his twofold capacity, as king of the upper and lower regions.

No. 33. A bas-relief, representing Priam in the act of supplicating Achilles to deliver to him the body of his son Hector.

No. 33*. A Greek inscription anciently placed under a statue of Jupiter Urius, which stood within a temple erected to that Deity, at the mouth of the Pontus. Presented by "Miss Mead.

No. 34. A bust of Severus, with the Imperial paludamentum.

No. 35. A bronze statue of a Roman Emperor, probably of Nero when he was young. The figure is represented in armour, which is most beautifully inlaid. It was found near Barking-Hall, in Suffolk on the estate of the Earl of Ashburnham. Presented in 1813, by the Earl of Ashburnham.

No. 36. A foot covered with a sandal. This and No. 30. belonged to the same statue.

No. 37. A sarcophagus, in the centre of which is the portrait of an elderly man, placed in the inside of a shield, which is supported by two Genii.

No. 38 . 
No. 38. A colossal foot of A pollo. Presented Room vi. by Sir William Hamilton.

No. 39. A figure of Victory, sacrificing a bull.

No. 40. A head of Faustina, the wife of Marcus Aurclius.

No. 41. A triangular base of a small candélabrum.

No. 42. A sepulchral cippus, with an inscription to Viria Primitiva.

No. 43. A swan in red marble.

No. 44. A votive altar dedicated to Silvanus.

No. 45. A head of Tiberius. Purchased at the sale of the late Fit. Hon. Edmund Burke.

No. 46. A Greek sepulchral monument; with a bas-relief, and an inscription to Isias, who was a native of Laodicea, and daughter of Mhetrodorus. Brought from Sinyma. Presented by INatthew Duane, Esq. and Thomas Tyrwhite, Esq.

No. 47. An eagle.

No. 48. A triangular base of a candelabrum, the sides of which are ornamented with the attributes of Apollo, namely, a griffin, a raven, and a tripod.

No. 49. A head of Plautilla.

No. 50. A votive altar dedicated to Diana.

No. 51. A sepulchral cippus, which appears never to have been used, a blank space being left for the inscription. 
ROOM VI. No. 52. A statue of Libera, holding a thyrsus antiquities. over her right shoulder, and a bunch of grapes in her left hand; at her feet is a panther.

No. 53. A head of Adonis.

No. 54. A head of an unknown female, the hair elegantly bound with broad fillets.

No. 55. A statue of Ceres crowned in the manner of Isis.

No. 56. A head of Nero.

No. 57. A votive statue of a man who is carrying a round leathern bucket suspended from his left arm. The head is covered with a conical bonnet, and a dolphin serves as a support to the figure.

No. 58. A sepulchral cippus, without an inscription. On the front, beneath a festoon, which is composed of fruits and foliage, and is suspended from the skulls of bulls, are two birls perched on the edge of a vase, out of which they are drinking.

No. 59. A Greek sepulchral urn, with a basrelief in front; it is inscribed with the names of Pytharatus and Herophilus. From the collectian of Sir Hans Sloune.

No. 60. A Grecian altar. Presented by Sir William Hamilton.

No. 61. A head of Augustus. Purchased at the sale of the late Right Hon. Edmund Burke.

No. 62 。 
No. 62. A Greek funeral monument of De- Rоoм vr. mocles, the son of Democles, with a bas relief, Asriguiriss and an inscription in eight elegiac verses. It was brought from Smyrna. Presented by Matthew Duane, Esq. and Thomas Tyrwhitt, Esq

No 63. A statue of Bacchus, represented as a boy about five years old. The head is crowned with a wreath of ivy, and the body is partly covered with the skin of a goat.

No. 64. The front of a votive altar, with an inscription for the safe return of Septimius Severus and his family from some expedition. The parts in the inscription which are erased contained the name of Geta, which, by a severe edict of Caracalla, was ordered to be erased from every inscription throughout the empire.

No. 65. A bust of Caracalla; the head only is antique.

No. 66. A votive statue of an elderly man, holding a basket of fish in his left hand.

No. $6 \%$. A votive altar, sacred to Bacchus. On the front, Silenus is represented riding upon a panther.

No. 68. A group of two dogs, one of which is biting the ear of the other in play.

No. 69. A bust of Marcellus, dressed in the Roman toga. 


\section{2}

гоом vr. No: 70. An unknown female head, with a ANTIRUITIEs. broad fillet across the forehead.

No. 71. A fragment of a colossal foot.

No. 72. A small statue of a Muse, sitting on a rock, and holding a lyre in her left hand.

No. 73. A small statue of Cupid bending his bow.

No. $3 *$ A bas-relief, representing a female Bacchante, dressed in thin floating drapery, through which the beautiful forms of her body, are perfectly apparent. With one hañd, which is held somewhat above her head, she holds a knife, and at the same time secures a portion of her robe, which is blown behind her. With the other hand, which is held downward, she carries the hind quarters of a kid. This picce of sculpture was anciently one of the ornamental figures on the triangular base of a candelabrum.

No.74. A small statue of Hercules, sitting on a rock.

No. 75. A bust of Gordianus Africanus the elder, dresed in the Roman toga.

No. 76. A colossal hand.

No.7. An unknown female hẹad. The sockets of the eyes are hollow, and have been originally fllled with coloured stones, or some other material.

No. 78 . 


\section{等3}

No. 78. The front of the cover of a magnifiROOM VI. cent sarcophagus. It represents a group of cattle Axtrouirass. on one side of which is an old Faun, and on the other a young Faun, both recumbent.

No. 79. A fragment of a mask of Bacchus. From the collection of Sir Irilliam IIamilton.

No. 80. A rotive foot, with a sandal Round the foot a serpent is twined, with its head resting on the summit, which terminates a little above the ankle.

No. 81. An earthen vase, which has two handles at the neck, and terminates in a point at the bottom, like an amphora. It was found in the baths of Titus, with above seventy others of the same sort; all of them contained the fine African sand, with which, when mixed with oil, the Athletæ rubbed their bodies before they exercised.

No.82. A votive foot, covered with a sandal, and having a serpent twined round it, in the same manner as is described at No. 80 .

No. 83. A mask of Bacchus.

No. 84. A sphinx, which anciently formed part of the base of a superb candelabrum.

No. 85. A head of Sabina.

No. 86. A small figure of a recumbent Satyr.

No. 87. A sepulchral cippus, without an incription. It is richly ornamented on the four sides with festoons of fruit.

No, 88 . 


\section{4}

800M VI. No. 88. An Egyptian tumbler, practising his A ATEQuiris. art on the back of a tame crocodile.

No, 89. A sepulchral cippus, with an inscription to M. Colius Superstes

No. 90. An unknown bust of a middle-aged man. The hair of the head and beard is short and bushy. The left shoulder is covered with part of the chlamys. The right shoulder and breast are uncovered. On the plinth is an inscription, signifving that L. Exilius Fortunatus dedicates the bust to his friend.

No. 91. A Greek sepulchral monument, with a bas-relief, and an inscription to Exacestes, and Metra his wife.

No. 92. A trophy, found on the plains of Marathon. Presented by John Walker, Esq.

No. 93. A sepulchral cippus, with an inscription to T. Claudins Epictetus:

No. 94. A head of Messalina.

No. 95. A torso of Hercules.

No. 96. A monumental inscription, cut from the front of a sepulchral cippus. It records the name of Claudia Tychen.

- No. 97. A statue, 3 feet 10 inches high, ending from the waist downwards in a terminus. In the right hand is a bunch of grapes, at which a bird, held under the left arm, is pecking.

No. 98. A rotive altar, with a dedicatory inserption to Dona Dea Annianensis. 
No. 99. A head of Jupiter Serapis. The ronмvr. paint, with which the face was anciently coloured, AmTrouries. is still discernible.

\section{SEVENTH ROOM. \\ ROMAN ANTIQUITIES.}

No. 1. An unknown statue; it is cloathed in room vir. the Roman toga.

Na. 2. A bust of a sleeping child, in altorelievo.

No. 3. A fragment of a frieze, representing two Cupids running a race, in cars draws by dogs; they appear to have just started from the carceres of a circus.

No. 4. A pig of lead, with the name of the Emperor Domitian inscribed upon it. It weighs 154 pounds. It was discoverel, in the year 173 !, under ground, on Hayshaw Moor, in the manor of Dacre, in the West Riding of Yorkshire. Bequeathed by Sir John Ingleby, Bart.

No. 5. Ditto, inseribed with the name of L. A ruconius Verecundus. It, weighs 8 i pounds. It was found near Matlock Bank in Derbyshire. Presented by Adam Wolley, Esq.

No. 6. A large sepulchral cippus, with an inscription to M. Clodius Herma, Annius Felix, and Tyrannus.

No. 7. A tragic mask.

No. 8 . 
room VIr. No. 8. The front of a sarcophaguts, with a Antsousizs. Greek inscription to M. Sempronius Neicocrates.

No. 9. A pig of lead, with the name of the Emperor Hadrian inscribed upon it. It weighs 39 pounds. It was found, in the year 1796 or 1797, in a farm called Snailbeach, in the parish of Westbury, 10 miles S.W. of Salop. Pre. sented by John Lloyd, Esq.

No. 10. Ditto, also inscribed with the name of the Emperor Hadrian. Its weight is 125 pounds. It was found in Cromford Moor, in Derbyshire. Presented by Peter Nightingale, Esq.

No. 11. A large sepulchral cippus, with an inscription to Agria Agatha.

No. 12. A statue of Septimus Severus, cloathed in the imperial paludamentum.

\section{EIGHTH ROOM.}

EGYPTIAN ANTIQUITIES.

FOom vir. No. 1. The coffin of an Egyptian mummy, sent to England by Edward Wortley Montagu, Esq. and presented to the Museum by $\mathrm{His}_{\mathrm{S}} \mathrm{MA}$ JEsty. In the left hand corner of this case is a conical vessel of baked clay, containing an embalmed Ibis.

No. 2. Two Egyptian mummies. That on the left hand, which has been elaborately and beautifully 
beautifully ornamented with coloured glass-beads, ROOM VIII. some of which still remain, was taken out of Axriquiriss. the coffin above-mentioned. That on the right hand, the face of which is gilt, and the other parts of the body ornamented with paintings, was taken out of the coffin which will be described in the next number. In the lower part of this case is a small Egyptian coffin of a square form; it contains the mummy of a child. The lid and sides of this coffin are covered with paintings.

No. 3. The coffin of an Egyptian mummy, found in one of the catacombs at Sakkara, about four leagues from Cairo, and sent to England, in the year 1722 , by Col. William Lethieullier, who bequeathed it to the Museum.

No. 4. A collection of vases, usually known by the name of Canopuses. The lids are severally ornamented, either with a head of Isis, Osiris, a hawk, a wolf, or a baboon.

No. 5. A collection of Egyptian idols, in bronze; among them are two sistrums.

No. 6. A collection of Egyptian idols, in wood; Egyptian idols of Roman work, apparently of the rime of Hadrian;-idols and amulets of the Basilidians, who spread their mysterious doctrines, and practised their magical arts, in Egypt, from the time of Hadrian to the fifth 
room virt. century;-Egyptian scarabæi, or beetles found ANTIQUITIES. in mummies;-small idols in basalt.

No. 7. A collection of Egyptian idols, in porcelain.

No. 8. Various fragments of statues in basalt, marble, and alabaster. Among them are a few perfect figures, namely, two of Harpocrates, one of a baboon, and another of an Apis. At the bottom of this case is a bas-relief, and some large idols in wood.

Opposite the entrance to this Room, and against the wall, is a frame containing the bones of an embalmed Ibis, which was presented by the Pight Hon. Sir Joseph Banks. Underneath is a manuscript taken from a mummy; it is written on Papyrus, in the Egyptian language, and was presented by $W m$. II Iamilton, Esq. as were also the fragments of another manuscript of the same kind, which are placed near it. On the right hand of the door is a frame, containing an Egyptian painting, taken from the breast of a mummy.

\section{NINTH ROOM.}

EGYPTIAN SCULPTURES.

The articles contained in this Room are principally those which were collected by the French in different parts of Egypt, and came into the possession of the English army, in consequence 
of the capitulation of Alexandria, in the month ROOM IX. of September, 1801. They were brought to England, in February, 1802, under the care ANTIQUITIES: of Col. Turner, and were sent, by order of His Majesty, to the British Museum. Such articles as did not form part of the abovementioned collection are particulurly specifieds in the catalogue.

No. 1. A large Egyptian sarcoplagus, of breccia, brought from the mosque of Saint Athanasius, at Alexandria. It is covered with hieroglyphics both within and without.

No. 2. Another large Egyptian sarcophagus of black granite, also covered with hieroglyphics, inside and outside. This sarcophagus, which was brought from Grand Cairo, was used by the Turks as a cistern, which they called "The "Lover's Fountain."

No. 3. A small mu ilated figure of Isis, sitting on the ground, and resting her arms upon her knees. An ear of corn is held in the left hand, and in front of the figure is the head of Orus. Presented, in 1767, by the Earl of Bute.

No. 4. A fragment of an Egyptian Deity, similar to No. 10.

No. 5. A sphinx, represented according to the custom of the Egyptians without wings. Presented, in 1767 , by the Earl of Bute.

$$
\text { Q } 2
$$

No. 6 . 
ROOM IX. AntJovities.

No. 6. A capital of an Egyptian column. Presented, in 1805, by Earl Spencer.

No. 7. An Egyptian monument, in which are sunk two square tablets, one of which is left blank, and in the other are represented two female figures standing side by side. These tablets are surrounded by hieroglyphics. From the the collection of Sir Hans Sloane.

No. 8. A figure of Isis, the size of life. She is represented sitting on the ground, resting her arms upon her knees, and holding an ear of corn in her right hand. In the front is the head of Orus,

No. 9. A mutilated Egyptian figure, kneeling on a square plinth, round which is a border of hieroglyphics.

No. 10. A large statue of an Egyptian Deity, sitting in a kind of chair, and resting its arms upon the thighs. In the left hand is held the sacred instrument called the Tau. The head of this Deity is that of a lion, the rest of the figure is human. The disc and the erect serpent's head have been knocked off from the upper part of this figure, but in the next statue they are nearly entire.

No. 11. Similar to No. 10.

No. 12. A fragment of a porphyry column.

No. 13. An Egyptian coffin, slightly resembling in its form the human figure. It has a single border of hieroglyphics round the outside. 
No. 14. A fragment of a porphyry column. Rоoм Ix.

No. 15. Part of the frieze of an Egyptian Anтiquirus. temple. It is covered with hieroglyphics on both sides. The upper part of the front of this frieze consisted of a row of birds, the legs of which are all that now remain. Presented by $\mathrm{H}_{\mathrm{IS}}$ Majestr.

No. 16. An Egyptian obelisk.

No. 17. Part of the frieze of an Egytian temple. It is covered with hieroglyphics on both sides. The upper part of the front of this frieze consists of a row of serpents. Presented by His Majesty.

No. 18. A small Egyptian figure with a beard, a short apron, and a terrific aspect. He is standing upright, but holding his arms downwards, a little apart from the body. 'The ornament upon the head is peculiar to the representation of this figure. From the collection of Charles Towneley, Esq.

No. 19. A head of an Egyptian sphinx. From the collection of Charles Towneley, Esq.

No. 20. A small Egyptian figure kneeling upon a square plinth, and supporting with his hands a kind of altar, in front of which, within a sunk tablet, is a figure of Osiris. Presented by Matthew Duane, Esq.

Nos. 21-22. Fragments of an Egyptian Deity, similar to No. 10. 
ROOM IX. No. 23. The Rosetta stone, containing three Aктолтries. inscriptions of the same import, one in hieroglyphies, another in the ancient vernacular language of Egypt, and another in the Greek language. These inscriptions record the services which Ptolemy the Vth. had rendered his country, and were engraved by order of the Migh Priests, when they were assempled at Memphis for the purpose of investing him with the royal prerogative. This stone was found near Rosetta.

No. 24. A colossal head of Jupiter Ammon, who was represented by the Egyptians with the head of a ram.

No. 25. An Egyptian obelisk.

No. 26. A colossal fist of very considerable magnitude.

No. $2 \%$. A colossal first, of a much smaller size than the preceding one. Presented, in 1805, by Earl Spencer.

No. 28. A fragment, covered with hieroslyphics. Presented, in 1805, by Earl Spencer.

No. 29. A fragment of a large sarcophagus, similar in its structure to Nos. 1. and 2.

No. 30. A fragment which was found at the foot of Pompey's Pllar, and is partly covered with hieroglyphics.

No. 31. An Egyptian bas-relief, consisting of 2 double range of figures. The upper range is imperfect, 


\section{3}

imperfect, half of the figures having been broken off. The lower range represents some priests armed with knives, with which they are sacrificing ROOM IX. bulls. It was found near Sakkara, four leagues from Grand Cairo. Presented, in 1767, by the Earl of Bute.

No. 32. A fragment of a porphyry column. Nos. 33-34. Statues of Egyptian Deities, similar to No. 10.

No. 35. A mutilated kneeling figure, supporting with both its hands an altar, on which a scarabæus is placed. Presented, in 1805, by Earl Spencer.

No. 35*. The lower part of an Egyptian figure, kneeling on a square plinth, round which is a border of hieroglyphics. Presented by his Royal Highness the Duke of Iork.

No.36. A votive column, on which is an inscription in Greek to the great Cod Serapis at Canopus. It was brought from Aboukir. Presented by Dr. Bancroft, Jun.

No. 37. A colossal hawk. Presented by Mr. T. Philipe.

No. 38. A fragment of an Egyptian Deity, similar to No. 10.

No. 39. A small mutilated Egyptian figure, kneeling on a square plinth.

The fragments of Mosaic pavement, (placed 


\section{4}

Room IX. For the present in this Room) were found at Axтв - Wiriz. Withington in Gloucestershire. They were-presented by Henry Brooke, Esq.

\section{TENTH ROOM.}

GREEK AND ROMAN SCULPTURE.

Room X. No. 1. A head of Juno, crowned with a a broad indented diadem.

No. 2. An upright narrow piece of marble, ornamented with branches of the olive and the vine.

No. 3 Cupid sleeping upon a lion's skin.

No. 3*. An epitaph on a dog. From the Collection of Sir Hans Sloane.

No 4. A head of Heraclitus.

No. 5. A head of Apollo.

No. 6. A head of a lion, being a fragment of a large sarcophagus.

No. 7. An oblong square basin of granite, similar to such as were used in the temples, to contain the water necessary for the purification of those who sought to gain admittance to the sacrifices.

No. 8. A mask cut from the cover of a large sarcophagus. From the Collection of Sir William Hamilton.

No. 9. A statue of an intoxicated Faun. 
No. 10. A terminal head of Libera.

No. 11. A head of a laughing Paun.

No. 12. A torso of a small statue of Venus.

No. 13. A small statue of a Muse, sitting on a rock, and playing on a lyre.

No. 14. A bust of a child, with the breast naked.

No. 15. A head of a female Bacchante.

No. 16. Small terminal heads of Bacchus and Libera, joined back to back.

No. 17. A small terminal head of Libera. From the Collection of Sir William Hamilton.

No. 18. Ditio, in yellow marble.

No. 19. Ditso, in red marble.

No. 20. Ditto, in reddish yellow marble, w ithanecklace composed of ivy leaves.

No. 21. A small terminal head of Libera in white marble, with the breast covered with drapery. From the collection of Sir Willicis Hamilton.

No. 22. A small terminal head of the bearded Bacchus. From the collection of Sir Wrilliam Hamilton.

No. 23. A small female head, the hair of which is formed of a distinct piece of marble, and is fitted to the head in the manner of a wig.

No. 24. A small head of a young man, covered with a helmet, which is ornamented with 
noom $\mathrm{x}$. the horns of a ram. From the collection of Sir ANTiQuities. William Hamilton.

No. 25. A small mask of Silenus. From the collection of Sir William Hamilton.

No. 26. A cylindrical piece of marble, which appears to have been part of the stem of a candelabrum. It is ornamented with four Griffins and two small candelabra.

No. 27. A fragment of 'a bas-relief, representing the head of an elderly man. It has the beard on the chin and the upper lip, and the hair of the head is short and curly. From the collecision of Sir William Hamilton.

No. 28. A bas-relief, representing a comic and a tragic mask.

No. 29. A fragment of a bas-relief representing the head of Antinous. From the collection of Sir William Hamilton.

No.30. A votive barrel, sacred to Bacchus.

No. 31. A small terminal head of the bearded Bacchus, in yellow marble. From the collection of Sir Hans Sloane.

No. 32. A votive horn, in marble, two feet long.

No, 33. A hear of Adonis, covered with the pyramidal hogd. The lower part of the face and neck is covered with drapery.

No. $33 *$. 


\section{7}

No. 33.* A piece of Mosaic pavement, found ROOM X́. at Woodchester, in Gloucestershire, Presented Antreutins. by Samuel Lysons, Esq.

No. 34. A statue of a Discobolus, who is represented at that precise moment of time which immediately precedes the delivery of the discus. It is an ancient copy in marble from the celebrated bronze statue executed by Myro.

No. 34*. A bas-relief, representing the arms of the Dacians and Sarmatians.

No. 35. A bust of an unknown Grecian lady represented in the character of Isis. It is gracefully terminated by the flower of the Nympha a Lotus, on which it appears to rest.

No. 36. A head of a Muse, crowned with a wreath of laurel.

No. 37. A small bust of Antoninus Pius; the head only is antique.

No.38. A head of a female chill. The hair is divided into plaits, which are twisted into a knot on the back part of the head. Some of the red paint, with which the hair was anciently coloured, is still visible.

No.39. A small scenic figure, sitting on a square plinth. The face is covered with a comic mask.

No. 40. A head of a child.

No. 41. A head apparently of a trumpeter. 


\section{8}

ROOM X. AsTiquTties。
No. 42. A head of one of the Dioscuri. No. 43. A fragment of a small head of Hercules, on the top of which is the skin of a lion's head. Presented by Thomas Hollis, Esq.

No. 44. A funeral mask which was used to cover the face of a female corpse. From the collection of Sir William IHamilion.

No. 45. A small head of Hercules. Presented by Thomas Hollis, Esq.

No. 46. A small unknown bust, with a military garment. The head is of yellow marble. Presented by Thomas Hollis, Esq.

No. 47. A small head of Hercules, very much injured by the decomposition of the marble. From the collection of Sir William Hamilton.

No. 48. The capital of a small column of the Ionic order. From the collection of Sir William Hamilton.

No. 49. A small unknown head. From the collection of Sir William Hamilton.

No. 50. A small head of Vulcan, covered with a cap. From the collection of Sir William Hamilton.

No. 51. A votive mask of a bearded Faun, Presented by Thomus Hollis, Esq.

No. 52. A small unknown female head, the hair of which is tied in a knot behind. From the collection of Sir William Hamilton.

NQ. 53. 


\section{9}

No. 53. A small head of Juno. Presented rooм x. by Thomas Hollis, Esq.

No. 54. A group, representing Venus and two Cupids.

No. 55. One of the handles of a vase. From the collection of Sir William Hamilton.

No.56. A fragment of a bas-relief, representing part of a female figure. From the collection of Sir William Hamilton.

No. 57. A bas-relief, representing a mask of a Faun.

No. 58. A left foot covered with a sandal.

No. 59. The right foot of a child.

No. 60. A hand of a female, holding a lock of hair. This fragment probably belonged to a statue of Venus, who was represented in the act of wringing the water from her hair. From the collection of Sir William Familion.

No.61. The right hand of a female holding a pipe.

No. 62. A lion's font, which probably has formed part of a tripod table.

No.63. The left hand and part of the arm of a female, probably Psyche, holding a butterfy.

No. 64. A lion's foot, which has been applied to the same purpose as No. 62 .

No. 65. The left hand of a female, stretched out upon a fragment of something unknown.

No. $66_{8}$ 
Rовм X. No. 65. The right hand of a youth holding, ANrreuiries. apparently, a fragment of a bow. This is probably part of a statue of Cupid bending his bow. No.67. The right hand of a child holding the head of a ram.

No. 68. A left foot, covered apparently with linen, round which bandages are fastened.

No, 69. A large votive patera with a basrelief on each side, one representing Silenus, and the other a Satyp. From the collection of Sir William Hamilton.

No. 70. A small fragment of a figure holding a bird.

No. 71. The left hand of a child holding a fragment.

No. 72. A torso of a male figure, the arms of which appear to have been raised above the head.

No. 73. A small mutilated figure. The right breast is naked, the other parts are entirely covered with dapery. It has a necklace from which a scarabrus is suspendled.

No. 74. A head of an eagle, which appears to have served as the hit of a sword. From the collection of Sir Dillian Hamillon.

No. 75. A votive patera, with a bas-relief on each side, one represeuting a mask of the beard ed Bacchus, and the other a panther. Fron the collection of Sir Wrillian IFumilhan. 
No. 76. A fragment of a serpent.

No. 77. A head of Apollo.

No. 78. A statue of Mercury sleeping upon a rock.

No. 79. A head of Cybele.

No. so. A head of a lion, which was a part of the same sarcophagus from which No. 6 was taken.

No. 81. A cistern of green basalt, anciently used as a bath. On the sides are carved two rings in imitation of handles, in the centre of which is a leaf of ivy.

No. 82. A head of Minerva.

No. 83. A colossal head of Antinous in the character of Bacchus, being crowned with a wreath of ivy.

No. 84. A small domestic fountain of a square form, which was used for sacred purposes.

No. 85. A bust of Minerva; the head only is antique; the helmet and the bust, which are of bronze, are, with some variations, copied from an ancient bust of Minerva, which was formerly in the Vatican, but is now at Paris.

No. 86. An upright narrow piece of marble arnamented with branches of the olive and t e pine.

No. 87. A head of Diana, the hair of which is drawn up from the sides, and tied in a knot at 
no um x. the top of the head. From the collection of Sir Axirguitiss. William Hamilton.

No. 88. A fragment of a bas-relief, representing three legs, which have belonged to two figures in powerful action, one of whom appears to have been aiming a blow at the other who is falling. Bequeathed by the late Charles Lambert, Esq.

No. 89. A head of Diana, somewhat similar to No. 87 , but of superior work.

No. 90. A head of Jupiter Serapis, in green basalt.

No. 91. A bas-relief representing the subject engraved upon a Greek sepulchral monument. Purchased by the Trustees.

No. 92. A head of Jupiter Serapis. From the collection of Sir IVillian Hamition.

\section{ELEVENTH ROOM.}

COINS AND MEDALS.

200M Xl.

This collection, the basis of which was formed, by the cabinets of Sir Hans Sloane and Sir Robert Cotton, has been from time to time enlarged by many valuable purchases and donations, but principally by the munificent bequest of the Rev. C.

M. Cracherode. 
M. Cracherode. It is comprehended under the Room $\mathbf{x t}$. three following heads.

$$
\begin{aligned}
& \text { 1. Ancient Coins. } \\
& \text { 2. Modern Coins. } \\
& \text { 3. Medals. }
\end{aligned}
$$

The first of these heads consists of Greek and Roman coins.

The Greek coins are arranged in geographical order, and include all those which are struck with Greek characters, in Greece or elsewhere, by kings, states, or cities, which were independent of the Romans. With this class are placed likewise the coins of free states and cities, which made use of either the Etruscan, Poman, Punic, Spanish, or other characters.

The Roman coins are placed, as far as it can be ascertained, in chronological order. They consist of the $A s$ and its divisions: Family or Consular coins: Imperial coins struck in Rome : Imperial coins struck in Egypt: Imperial coins struck with Greek characters, in different states and cities, which were subject to the Romans: Imperial coins struck in the Roman colonies: Imperial coins struck with Punic characters : Contorniates.

The second head, comprising modern coins, consists of Anglo-Saxon, English, Anglo-Gallic, Scotch, and Irish coins, and likewise the coins 


\section{4}

Room xI. of foreign nations. This class is arranged accordAntiguities. ing to the respective countries to which the coins belong, those of each country being kept separate.

The third head, which comprises a class considerably more modern than either of those which precede it, consists of Medals struck in our own country, and of those which have been struck abroad. These are arranged in the same manner as the modern coins.

\section{ANTE-ROOM.}

ANTE-room. No. 1. In the centre of the Ante-Room, at the head of the stairs, is placed the celebrated Barberini vase, which was for more than two centuries the principal ornament of the Barberini collection. This vase was purchased of Sir William Hamilton, nearly thirty years ago, by the Duchess of Portland, since which period it has been more generally known by the name of the Portland $V$ ase. It was found about the middle of the sirteenth century, two miles and a half from Rome, in the road peading to Erascati. At the time of its discovery, the vase was cnclosed in a marble sarcophagus, within a sepulchral chamber, under the mount called Monte del Grano. The material of which the vase is formed, is glass; the figures, which 
are executed in relief, are of a beautiful opaque white, and the ground, which is in perfect harAVTE.ROON. mony with the figures, is of a dark transparent blue. The subject of these figures is extremely obscure, and has not hitherto received a satisfactory elucidation; but the design and the sculpture are both truly admirable.

This superb specimen of Greek art was deposited in the British Museum, in 1810, by his Grace the present Duke of Portland.

No. 2. An ancient painting, in fresco, representing deer, found in a subterraneous chamber at Scrofano, about sixteen miles from liome. From the collectian of Sir William Hitamilton.

No. 3. A bas-relief, in stucco, representing a winged boy, or genius, carrying a pedum across his right shoulder. From the collection of Sir William Hamilton.

No. 4. An ancient painting in fresco, representing a female figure holding a patera on which a vase is placed. Presented, in 17\%1, by the Earl of Exeter.

No. 5. An ancient painting, in fresco, re. presenting two femaies seated, in the arabesque style, on the curling branches of a plant; one of them is holding a vase, the other a tambourin. Between these figures is a bas-relief, in stucco, representing a human head surrounded with ivy, 


\section{6}

NTE-Rnom. and underneath are two birds drinking out of a Antiouiriss. well. Presented by Thomas Hollis, Esq.

\section{IWELFTH ROOM.}

COLLECTION OF SIR WILLIAM HAMILTON.

200м XII. (Cases 1, 2, 3, 4.) Penates, or household Gods, in bronze: many of them are in fine preservation, and of good sculpture, and are valuable on many accounts, particularly for the, variety of attributes by which they are severally: distinguished. In these cases are also rontained some bronze vessels, remarkable either for their size or elegance.

(Case 5) A raven, the size of life; and five. large candelabra of bronze. The raven was presented, 1777, by Lord Seaforth. It is of the finest workmanship, and has probably belonged to a statue of Apollo.

(Case 6) Specimens of ancient glass. The principle articles are four cinerary urns. One of them has the leaden covering, in which it was preserved; and another contains the burnt bones, and the asbestos cluth, which prevented the ashes of the body from mixing with those of the funeral pile. These articles are accompanied by a great number of lachrymatories, and various other vessels, 
vesse's, and fragments of vessels, of different ROOM XIr. formsitl colours, the whole of which afford ample proofs of the ingenuity of the Ancients, and of the great knowledge they possessed in the art of fabricating glass, and of imparting to it whatever colour or form they chose.

(Case 7.) Miscellaneous bronzes.

(Case 11.) Necklaces, ear-rings, armillæe, and various other trinkets in gold, several of which are enriched with precious stones. Among the golden antiquities in this case is a bulla, and a large patera: the latter is embossed with bulls, and was found at Gergenti in Sicily. This case contains also a large collection of scarabæi, and some engraved gems: a valuable portion of the latter was bequeathed by the Rev. C. M. Cracherode. A piece of small mosaic work, and a few specimens of ancient art, executed in silver, are likewise among the articles included in this case.

(Case 15.) Fragments in terracutta. They consist chiefly of small heads, some which are well executed, and some are valuable as exhibiting specimens of the Roman head dresses.

(Cases 28, 32, 36.) Fragments of bas-reliefs, in terracotta.

(Case 37.) Specimens of ancient armour in bronze; consisting of helmets, breast plates, standards, swords, belts, heads of spears, points of arrows, \&ic. 


\section{8}

ROOM XIr.

ANTIQUTITE. delabra, in bronze.

(Cases 39, 40, 41, 42.) Miscellaneous antiquities in bronze, comprising steelyards and scales; knives, pateræ, and simpula; mirrors, lamps, bells, and mortars; measures and winestrainers; large vessels for culinary and other purposes; several small candelabra; a lectisternium; and many other articles.

(Case 43.) Stamps for sealing casks.

(Case 44.) A large collection of Roman weights.

(Case 45.) Votive offerings in bronze.

(Case 46.) Handles of knives, and fragments of lectisternia.

(Case 47.) Specimens of sculpture in ivory: amongst them is a beautiful head of Mercury. A great variety of Tesseræ in ivory, bronze. crystal, agate, and terracotta, many of which were tickcts of admission to the theatres. In this case also is a considerable number of styles for writing on wax tablets, pins for the hair, bodkins, and needles both for sewing and netting.

(Case 48.) Dice and tali, formed of various substances.

(Case 49.) A large dish of Oriental jasper, two cups of rock crystal, \&c.

(Case 50.) Armillæ or bracelets, and various unknown ornaments in bronze. 
(Case 51.) Specimens of Roman enamel, and ROOM XIr. inlaid work. Figs, and other vegetable substances, which were found in a calcined state at Antiquites: Herculaneum.

(Cases 52-60.) A very rich collection of Roman lamps in terracotta.

(Case 61.) Some articles in bronze; the use to which they were applied is unknown.

(Case 62.) Fragments of chains, bits, spurs, and ornaments for harness.

(Case 63.) Antiquities in iron.

(Cases 64, 65, 66.) Specimens of ancient painting from Herculaneum. In these cases are also contained two bricks, taken out of the ruins of a large city, supposed to have been Babylon, near the town of Hillah, on the river Euphrates; on each of these bricks there is an inscription in unknown characters.

(Cases 67, 68, 69.) Specimens of bas-relief in stucco, from the walls of Herculaneum.
(Case 70.) Celts.
(Case 71.) Various instruments used by the Ancients; namely, rulers, compasses, nippers, chissels, plummets, probes, spatulæ, \&c.

\section{(Case 72.) Celts.}

(Case 73.) Buckles used by the Ancients for different purposes.

(Case 74.). Fibula or broaches. 
RoOM Xil. Antiguities.

(Case 75.) Hinges and nails.

(Case 76.) Specimens of locks and keys.

(Cases 77.78.) I andles and other parts of vases.

The intermediate and subsequent cases in this room are appropriated to the reception of the Greek Vases, of which the greatest number was found in sepulcbres, wirbin those parts of the kingdom of Naples, which came under the denomination of Magna Græcia. The greater part of these vases are ornamented with paintings, representing a variety of subjects, chiefly mythological, the compositions of which are truly elegant. The forms of the vases are much varied, and are equally simple and beautiful.

\section{THIRTEENTH ROOM.}

\section{PRINTS AND DRAWINGS.}

ROOM xm. In this room is deposited the extensive and valuable collection of prints and drawings, the most important part of which was bequeathed by the Rev. C. M. Cracherode.-The contents of this Room, as well as those of the cnins and medals, can be seen only by a few persons at a time, and by particular permission.

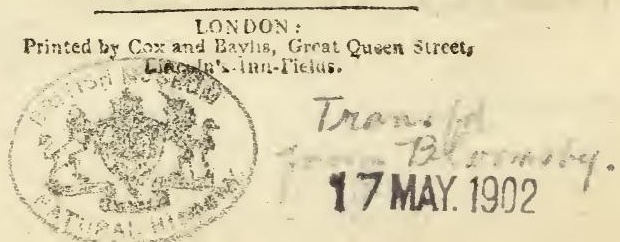





